\title{
Optimizing ethanol and bioelectricity production in sugarcane biorefineries in Brazil
}

\author{
Dilip Khatiwada a, b, *, Sylvain Leduc ${ }^{\text {b }}$, Semida Silveira a, Ian McCallum ${ }^{\text {b }}$ \\ a Division of Energy and Climate Studies, KTH Royal Institute of Technology, Brinellvägen 68, SE-100 44 Stockholm, Sweden \\ ${ }^{\mathrm{b}}$ Ecosystems Services and Management (ESM) Program, International Institute for Applied Systems Analysis (IIASA), Schlossplatz 1, A-2361 Laxenburg, \\ Austria
}

\section{A R T I C L E I N F O}

\section{Article history:}

Received 15 April 2014

Received in revised form 4 May 2015

Accepted 4 June 2015

Available online $\mathrm{xxx}$

\section{Keywords:}

Second generation bioethanol

Bioelectricity

Systems optimization

\begin{abstract}
A B S T R A C T
In sugarcane biorefineries, the lignocellulosic portion of the sugarcane biomass (i.e. bagasse and cane trash) can be used as fuel for electricity production and/or feedstock for second generation (2G) ethanol. This study presents a techno-economic analysis of upgraded sugarcane biorefineries in Brazil, aiming at utilizing surplus bagasse and cane trash for electricity and/or ethanol production. The study investigates the trade-off on sugarcane biomass use for energy production: bioelectricity versus $2 \mathrm{G}$ ethanol production. The BeWhere mixed integer and spatially explicit model is used for evaluating the choice of technological options. Different scenarios are developed to find the optimal utilization of sugarcane biomass. The study finds that energy prices, type of electricity substituted, biofuel support and carbon tax, investment costs, and conversion efficiencies are the major factors influencing the technological choice. At the existing market and technological conditions applied in the upgraded biorefineries, $300 \mathrm{PJ} \mathrm{y}^{-1} 2 \mathrm{G}$ ethanol could be optimally produced and exported to the $\mathrm{EU}$, which corresponds to $2.5 \%$ of total transport fuel demand in the EU. This study provides a methodological framework on how to optimize the alternative use of agricultural residues and industrial co-products for energy production in agro-industries considering biomass supply chains, the pattern of domestic energy demand, and biofuel trade.
\end{abstract}

(c) 2015 Elsevier Ltd. All rights reserved.

\section{Introduction}

Sugarcane is one of the key renewable sources in Brazil. In 2013, it comprised $19 \%$ of the country's energy matrix [1]. Sugarcane juice, bagasse (stalk fibers: fibrous residue left over after squeezing sugarcane for its juice), and sugarcane leaves/tops (straw, also known as trash) each represents one-third of sugarcane energy content $[2,3] .40 \%$ of the fuel used in Otto-cycle engines (light duty vehicles) comes from first generation sugarcane juice ethanol in Brazil $[3,4]$. However, the lignocellulosic portion of the sugarcane biomass, which includes bagasse and trash, is still underutilized [5-11]. Surplus bagasse obtained in sugarcane mills and trash left or burnt in the field during harvesting can also be collected and

\footnotetext{
* Corresponding author. Division of Energy and Climate Studies, KTH Royal Institute of Technology, Brinellvägen 68, SE-100 44 Stockholm, Sweden.

E-mail addresses: dilip.khatiwada@energy.kth.se (D. Khatiwada), leduc@iiasa.ac. at (S. Leduc), semida.silveira@energy.kth.se (S. Silveira), mccallum@iiasa.ac.at (I. McCallum).
}

used for energy production. Bagasse and trash can be alternatively used as fuel for power (electricity) generation or feedstock for second generation biofuel.

There is room for upgrading the existing sugarcane mills as there is plenty of surplus sugarcane biomass (i.e. cane trash and bagasse) readily available. Cane trash and bagasse also have similar fuel characteristics, making them suitable for energy production [12]. There are several biomass conversion technologies, for that purpose, for example, cogeneration systems, thermochemical, and biochemical processes [13-17]. In this context, it is important to analyze alternatives and determine the best suitable option for optimally producing energy services and diversifying the industry. Both techno-economic and environmental performance need to be considered. A concept of 'biorefinery', which is analogous to the 'oil-refinery', is currently being developed for the conversion of lignocellulosic biomass, and simultaneous production of commercial liquid biofuels, heat and power, and a wide range of bioproducts $[18,19]$. The utilization of lignocellulosic biomass feedstock (e.g. crop harvest residues: straw/trash and industrial coproducts: bagasse) for biofuel production would be preferable 
considering the potential impacts of sugar/starch and oil seeds based biofuel production on food security and land use changes $[16,20]$. Biomass based advanced cogeneration technologies for electricity generation are quite mature and commercially available $[21,22]$ while second generation biofuel from lignocellulosic biomass has not yet become an industrial reality due to high investment and production costs [16,23]. Meanwhile, the soaring biofuels demand, especially due to renewable mandates and targets in many countries, is promoting global market formation and trade of biofuels [24]. Therefore, domestic demand, international biofuels market/trade, and the completion with electricity generation from the use of lignocellulosic biomass should be taken into account while selecting the suitable biofuel/bioenergy pathways. This study considers the sugarcane mills operating in one of the sugarcane producing states in Brazil, and their upgrading into biorefineries for producing bioelectricity and/or second generation (2G) ethanol using sugarcane biomass. Sugarcane bagasse and leaves/trash can be used in the production of bio-products [25] but the utilization of sugarcane biomass for non-energy production is beyond the scope of this paper. The study investigates the best technological options second generation ( $2 \mathrm{G}$ ) ethanol (2G option) or bioelectricity (electricity option) - for converting sugarcane biomass to useful energy products.

A number of studies have performed the techno-economic analysis of biofuel production at the plant level [6,7,9,11,26-28]. Seabra et al. (2010) have evaluated the techno-economic performance of thermochemical and biochemical conversion of sugarcane residues, considering sugarcane mill clustering [26]. Walter and Ensinas (2010) have described the technological pathways of biofuel production from sugarcane biomass and analyzed the impact of process integration with a conventional sugarcane distillery [7]. Systems performance is simulated for the technical, economic and environmental merit of power generation and ethanol production from sugarcane residual biomass, considering conversion plants adjacent to a sugarcane mill [6]. Dias et al. (2011) have performed simulation studies to determine the suitable option when selecting second generation or bioelectricity from the sugarcane biomass feedstock [9]. Macrelli et al. (2012) have described the competitiveness of second generation ethanol from sugarcane bagasse and leaves [10]. Lago et al. (2012) have demonstrated the positive conditions for the development of second generation ethanol derived from sugarcane biomass (bagasse and cane trash) in Brazil considering different industrial scenarios [29]. Dias et al. (2012) have examined how process optimization increases the production of second generation ethanol in sugarcane distilleries [11]. Recently, Furlan et al. (2013) and Dias et al. (2013) have investigated the economic advantages of a flexible (able to switch between $2 \mathrm{G}$ ethanol and bioelectricity production) sugarcane biorefinery [30,31]. Some authors claim that lignocellulosic ethanol may require policy support for implementation [32]. In addition, Dias et al. (2012) have simulated stand-alone and integrated second generation ethanol production from sugarcane biomass considering different technological scenarios [28]. Tittmann et al. (2010) have presented a spatially explicit technoeconomic optimization model of bioenergy and biofuels production system in California, considering location/size of bioenergy plants, conversion technologies, and feedstock profile and its supply chain configuration [33]. The model aims at maximizing the profit of a biofuel industry at given feedstock price, transportation cost, conversion cost, and price for fuels, electricity, and coproducts. However, no analysis has been carried out at the regional level yet, considering the entire biofuels production chain in general and the sugarcane biofuel (1G ethanol and 2G ethanol) production chain in particular. In addition, previous studies have not addressed the climate impacts or GHG offsets of the biofuel production systems. In addition to exploring optimal technological options, this study also presents the dynamics of the total costs and lifecycle emissions by internalizing the costs of emissions in the optimization model.

This study performs a techno-economic analysis for the bulk of sugarcane production area and industries located in the Brazilian state of Sao Paulo (SP). Biofuel production and international trade have been gradually growing over the last decade [34]. Therefore, it is important to understand how policies and economic/market factors/forces (e.g. price, carbon tax, biofuel support, etc.) affect the international trade of liquid biofuels. The trade of $2 \mathrm{G}$ ethanol to the European Union (EU) is taken into account here. The study considers that ethanol produced from sugarcane juice (1G ethanol) through fermentation is domestically consumed while the second generation (2G) ethanol, if produced, can be exported to the EU. Bioelectricity produced is fed into the grid and utilized in Brazil. 1G ethanol is already mature and commercially competitive. However, $2 \mathrm{G}$ ethanol is still not produced in commercial scale. Therefore, we scrutinize the technological choices and the role of market and policy instruments for energy (2G ethanol and/or bioelectricity) production from sugarcane biomass, also looking into international trade of $2 \mathrm{G}$ ethanol.

The study examines the alternative uses of sugarcane biomass (i.e. bagasse and cane trash) for $2 \mathrm{G}$ ethanol and/or bioelectricity production in the state of Sao Paulo in Brazil. The study performs the techno-economic optimization analysis of sugarcane mills, assuming technological improvements of existing mills. There is still a limited amount of research in modeling of biomass supply chains when it comes to investigating the impact of technological change, policy drivers/incentives, and market volatilities [35]. The study considers how the energy prices, conversion costs, and policy instruments such as biofuel support and carbon tax affect the choice of technology ( $2 \mathrm{G}$ ethanol option or electricity option), including the export of bioethanol to the EU. This paper aims to complement existing research studies, which are mainly focused on optimization of the economic and environmental benefits of biorefineries at the plant level in Brazil and other countries, by examining the costs and emissions of the entire supply chains, as well as the interactions with external parameters (e.g. energy prices, biofuel support, carbon tax, and international biofuel trade) in providing sustainable energy services for the welfare of the region.

The BeWhere model is used to determine the choice of technological improvements. The model is spatially explicit and has previously been applied for assessing the optimization of bioenergy production, mainly aiming at identifying the optimal location and size of biomass conversion units in Europe, see Refs. [36-39]. Sugarcane biomass is a geographically dependent renewable resource. It is important to develop an optimization model for determining suitable size/location of biofuel plants and conversion technologies, considering biomass supply, transport costs, and energy demand/prices. As the location and size of sugarcane mills is fixed in this study, we only simulate the technological options using the sugarcane biomass (bagasse and trash). This spatially explicit study is the first study of its kind in the Brazilian context in which sugarcane biomass - agricultural residue (tops/leaves or trash) and agro-industrial co-product (bagasse) - is used for energy production in sugarcane biorefineries. The study also provides important information on lifecycle emissions and costs/prices of advanced biorefineries using lignocellulosic sugarcane biomass in Brazil. It shall contribute for further development of the BeWhere model when the country seeks alternative pathways for producing modern bioenergy services, considering all features of the spatial modeling approach. Many developing countries have a huge potential to harness bioenergy/biofuel derived from crop residues (e.g. sugarcane trash, rice husk, straw, etc.) [40-42]. This model 
could be useful for identifying the optimum utilization of residual biomass or crop residues in these developing countries in terms of suitable technological options (e.g. conversion into $2 \mathrm{G}$ advanced biofuel or efficient cogeneration technologies), size/location of biofuel plants, policy instruments (incentive or biofuel support), costs/prices, and market factors.

The study is organized in five sections. Following this introduction, sugarcane mills, bioenergy systems, and upgraded technological options are described in Section 2. Section 3 presents the methodology and research approach adopted, indicating data sources and model inputs used in the simulation. The estimation of systems costs and lifecycle GHG emissions are also carried out. Results and discussion are presented in Section 4. Finally, concluding remarks are made in Section 5 with an emphasis on the main policy implications of the study.

\section{Sugarcane mills and bioenergy systems}

Sugarcane mills are being converted into biorefineries to produce more energy products and services. In Brazil, approximately

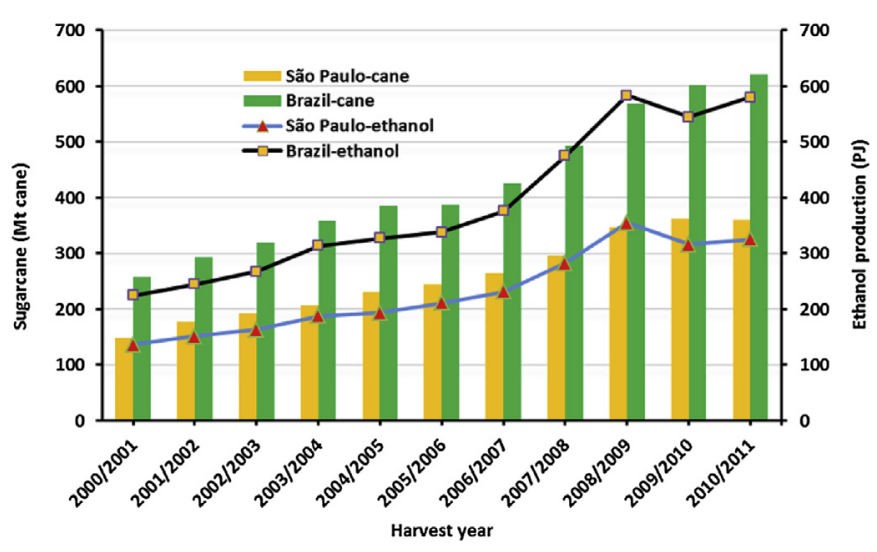

Fig. 1. Trend of sugarcane and ethanol production in Sao Paulo state and Brazil [4] Note: primary and secondary $y$-axis represent the total sugarcane production (million tonnes or Mt) and ethanol production in Peta Joule (PJ) respectively; $1 \mathrm{PJ}$ is equal to 47.2 million liters.
$40 \%$ of the sugarcane produced in the harvest years 2008/09 and 2009/10 was used to produce sugar and the rest was used for ethanol production. The state of Sao Paulo (SP) alone produces $60 \%$ of all sugarcane in Brazil [4], see Fig. 1. In this study, we assume that all existing sugarcane mills in the state SP are transformed into biorefineries focused on energy products. This means that sugar demand would have to be met by other sugarcane producing states in Brazil.

After harvesting, sugarcane is crushed to extract the juice. The juice is used to produce first generation $(1 \mathrm{G})$ ethanol. Bagasse is the fibrous residue left after extraction of the juice and it is combusted in a boiler, for production of heat and electricity. The average bagasse availability in Brazil is $28 \%$ (at 50\% moisture content) of the sugarcane production. During sugarcane harvesting, abundant sugarcane trash/waste (i.e. tops, leaves) is left in the fields, which can also be used as fuel in cogeneration plants. Trash yield is $280 \mathrm{~kg}$ ( $50 \%$ moisture) per tonne of cane stalk. $50 \%$ of the cane trash is left in the field to maintain soil quality [5]. Therefore, $50 \%$ trash is available for bioenergy conversion, considering the elimination of burning practices in the state of Sao Paulo (see Table 1). It should be mentioned that the optimal amount of cane trash to be left in the sugarcane field, considering both economic and environmental benefits of using it has not been investigated yet [3].

\subsection{Sugarcane bioenergy systems: the choice of technology}

The study includes three technologies: one conventional technology and two upgraded technologies, viz., efficient cogeneration systems for electricity generation (electricity option) and second generation (2G) ethanol through biochemical conversion of sugarcane biomass ( $2 \mathrm{G}$ ethanol option), (Fig. 2). Table 1 shows the key parameters and characteristics of the biorefineries considered in this study, while Table 2 presents the conversion efficiencies in the three technological options simulated.

The upgraded technologies use the surplus sugarcane biomass (bagasse and trash) for the generation of $2 \mathrm{G}$ ethanol and/or bioelectricity, in addition to the production of $1 \mathrm{G}$ ethanol from sugarcane juice. It is important to note that approximately $65 \%$ of the sugarcane biomass (i.e. bagasse and trash) is available for conversion to bioelectricity or $2 \mathrm{G}$ ethanol in the upgraded options

Table 1

Characteristics of sugarcane biorefineries considered in this study.

\begin{tabular}{|c|c|c|c|c|}
\hline \multirow{3}{*}{ Parameters } & \multirow{3}{*}{ Values $^{\mathrm{d}}$} & \multicolumn{3}{|l|}{ Technological options } \\
\hline & & \multirow[t]{2}{*}{ Conventional technology } & \multicolumn{2}{|l|}{ Upgraded } \\
\hline & & & Electricity option & 2G option \\
\hline Process capacity $^{\mathrm{a}}$ & 2 Mt cane per year & $\mathrm{x}$ & $\mathrm{x}$ & $\mathrm{x}$ \\
\hline Juice ethanol yield & $91 \mathrm{~L} / \mathrm{t}$ cane & $\mathrm{x}$ & $\mathrm{x}$ & $\mathrm{x}$ \\
\hline Conventional cogeneration plant & $22 \mathrm{bar} / 300^{\circ} \mathrm{C}$ & $\mathrm{x}$ & - & - \\
\hline Efficient cogeneration plant ${ }^{\mathrm{b}}$ & $90 \mathrm{bar} / 520^{\circ} \mathrm{C}$ & - & $\mathrm{x}$ & $\mathrm{x}$ \\
\hline Bagasse availability & $280 \mathrm{~kg} / \mathrm{t}$ cane (50\% moisture content) & $\mathrm{x}$ & $\mathrm{x}$ & $\mathrm{x}$ \\
\hline Unburned harvesting & $100 \%$ & $\mathrm{x}$ & $\mathrm{x}$ & $\mathrm{x}$ \\
\hline Total trash yield & $280 \mathrm{~kg} / \mathrm{t}$ cane (50\% moisture content) & $\mathrm{x}$ & $\mathrm{x}$ & $\mathrm{x}$ \\
\hline Trash availability $^{\mathrm{c}}$ & $70 \mathrm{~kg}$ dry $/ \mathrm{t}$ cane $(50 \%$ collection $)$ & - & $\mathrm{x}$ & $\mathrm{x}$ \\
\hline $\begin{array}{l}\text { Sugarcane biomass (bagasse and trash) } \\
\text { available for electricity and/or } 2 \mathrm{G} \text { ethanol production }\end{array}$ & $65 \%$ & - & $\mathrm{x}$ & $\mathrm{x}$ \\
\hline Surplus electricity generation & $150 \mathrm{kWh} / \mathrm{t}$ cane & - & $\mathrm{x}$ & - \\
\hline Second generation ethanol production & $41 \mathrm{~L} / \mathrm{t}$ cane (i.e. $300 \mathrm{~L} / \mathrm{t}$ dry cane biomass) & - & - & $\mathrm{x}$ \\
\hline Project year & 25 years & $\mathrm{x}$ & $\mathrm{x}$ & $\mathrm{x}$ \\
\hline Interest rate & $10 \%$ & $\mathrm{x}$ & $\mathrm{x}$ & $\mathrm{x}$ \\
\hline
\end{tabular}

a This capacity is also used as the base for analyzing costs, see Section 3.1 and [9].

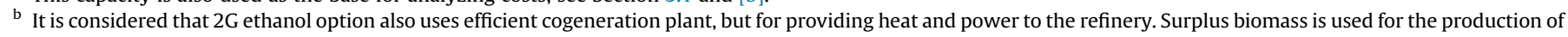
ethanol.

c $50 \%$ trash is only available for upgraded technologies.

d Sources: Juice ethanol yield [6], Surplus sugarcane biomass (authors' estimation based on efficient cogeneration (CHP) plant), surplus electricity generation [21], Second generation ethanol production [43]. 

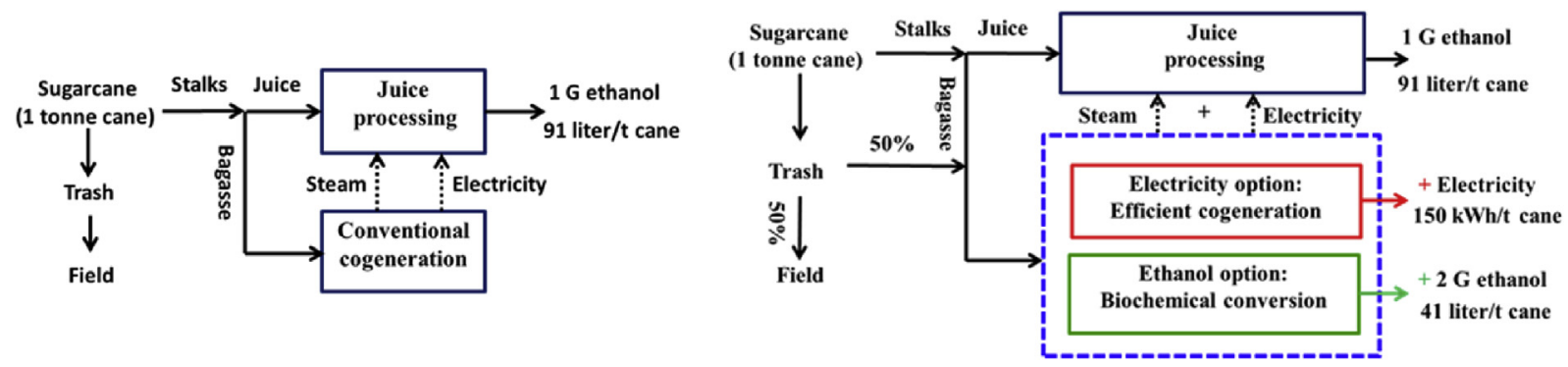

Fig. 2. Technological options: Conventional technology (left) and Upgraded technologies (right).

Table 2

Conversion efficiencies of biorefineries (PJ/Mt cane).

\begin{tabular}{|c|c|c|c|}
\hline \multirow{3}{*}{ Energy products } & \multicolumn{3}{|l|}{ Technological options } \\
\hline & \multirow{2}{*}{ Conventional technology } & \multicolumn{2}{|l|}{ Upgraded } \\
\hline & & Electricity option & 2G ethanol option \\
\hline Juice or $1 G$ ethanol & 1.929 & 1.929 & 1.929 \\
\hline Electricity & - & 0.540 & - \\
\hline $2 \mathrm{G}$ ethanol & - & - & 0.868 \\
\hline Total energy (PJ/Mt cane) & 1.929 & 2.469 & 2.797 \\
\hline
\end{tabular}

Notes: juice ethanol yield: $91 \mathrm{~L} / \mathrm{t}$ cane, $2 \mathrm{G}$ ethanol yield: $41 \mathrm{~L} / \mathrm{t}$ cane, electricity generation: $150 \mathrm{kWh} / \mathrm{t}$ cane (see Table 1 for references).

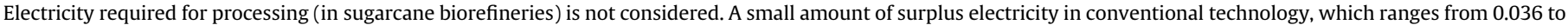
$0.09 \mathrm{PJ} / \mathrm{Mt}$ cane (i.e. $10-25 \mathrm{kWh} / \mathrm{t}$ cane, is also neglected.

(see Table 1). Bioelectricity can be sold to the grid while $2 \mathrm{G}$ ethanol can be exported to the EU to meet the biofuel target in the transport sector or used in Brazil if exports do not have benefits.

\subsubsection{Business as usual/conventional technology}

The business as usual or conventional technology only produces ethanol from sugarcane juice and bagasse is combusted to generate heat and power required for the sugarcane mills using backpressure steam turbine cogeneration systems at low levels of pressure and temperature $\left(\sim 22\right.$ bar $\left./ 300{ }^{\circ} \mathrm{C}\right)[3,44]$. The conventional sugarcane mills are self-sufficient in their internal energy requirements using bagasse as a fuel in boilers with a little or no electricity sold to the grid $[3,6]$. It is assumed that there is no surplus bagasse or electricity in the conventional mills as the sugarcane mills are traditionally designed to meet the internal energy requirements. Generation of a small amount of surplus electricity (i.e. $10-25 \mathrm{kWh} / \mathrm{t}$ cane) in the conventional sugarcane mills [6] is neglected.

\subsubsection{Upgraded technology: electricity option}

In sugarcane industries, cogeneration plants are being upgraded to produce surplus electricity in Brazil. Cogeneration (i.e. condensing-cum-extraction steam turbine) with high pressure boilers and turbines (up to 105 bars and $525{ }^{\circ} \mathrm{C}$ ) are mature and commercially available, and can produce $150 \mathrm{kWh} / \mathrm{t}$ cane of surplus electricity, utilizing excess bagasse and trash/residues [21]. The surplus electricity is connected to the grid. It should be pointed out that bioelectricity is mainly produced in the dry season, complementing the electricity from hydropower, and thereby reducing the use of fossil based power generation at the margin.

\subsubsection{Upgraded technology: $2 G$ ethanol option}

Sugarcane biomass (bagasse and trash) basically contains cellulose, hemicellulose and lignin. Thus it can be converted into fermentable sugars and then biofuel. At present, conversion of lignocellulosic materials (e.g. agricultural residue: cane trash, and agro-industrial co-product or residue: bagasse) to ethanol is not commercially available and still in the phase of development. Several studies have been done, investigating different conversion processes and their techno-economic performance $[6,7,9-11,26]$. In this study, the biochemical conversion of sugarcane biomass is used. Fig. 3 shows the structure of upgraded sugarcane biorefinery, including the $2 \mathrm{G}$ ethanol conversion processes. The process consists of steam explosion pretreatment of biomass, followed by the enzymatic hydrolysis, fermentation and distillation. Solid residues (i.e. lignin) are used as fuel in the boiler. Pentose-rich stream is biodigested to produce boiler fuel: biogas. Surplus heat and electricity are not considered in this route.

\section{Methodological approach and data sources}

\subsection{Methodology}

Biofuel models and optimization tools can be used to address the sustainability issues associated with biofuel supply chains in terms of environment, society, and economy [45]. In this study, a mixed integer linear program (MILP) [46], BeWhere, is used to optimize the choice of technology for producing energy products and services in sugarcane biorefineries. A detailed description of the model can be found in the previous literature [47,48]. The model has been used in several optimization studies for bioenergy production, especially from forest and wood residues in the EU [37,38,49]. Fig. 4 provides a schematic sketch of the model as applied in this study on energy production from agricultural feedstock in Brazil. The model is spatially explicit and minimizes the costs of the entire biofuel supply chain of sugarcane bioenergy systems, including sugarcane production (agricultural practices), feedstock transportation, biomass processing, and biofuel transportation. The costs for emitting GHG emissions, i.e. carbon tax, are also considered. It should be noted that the Bewhere model is robust and it has been used in a number of spatially explicit optimization studies in making decisions on the choice of technological options for energy production from the same lignocellulosic feedstock. For example, the selection on combined heat and power 


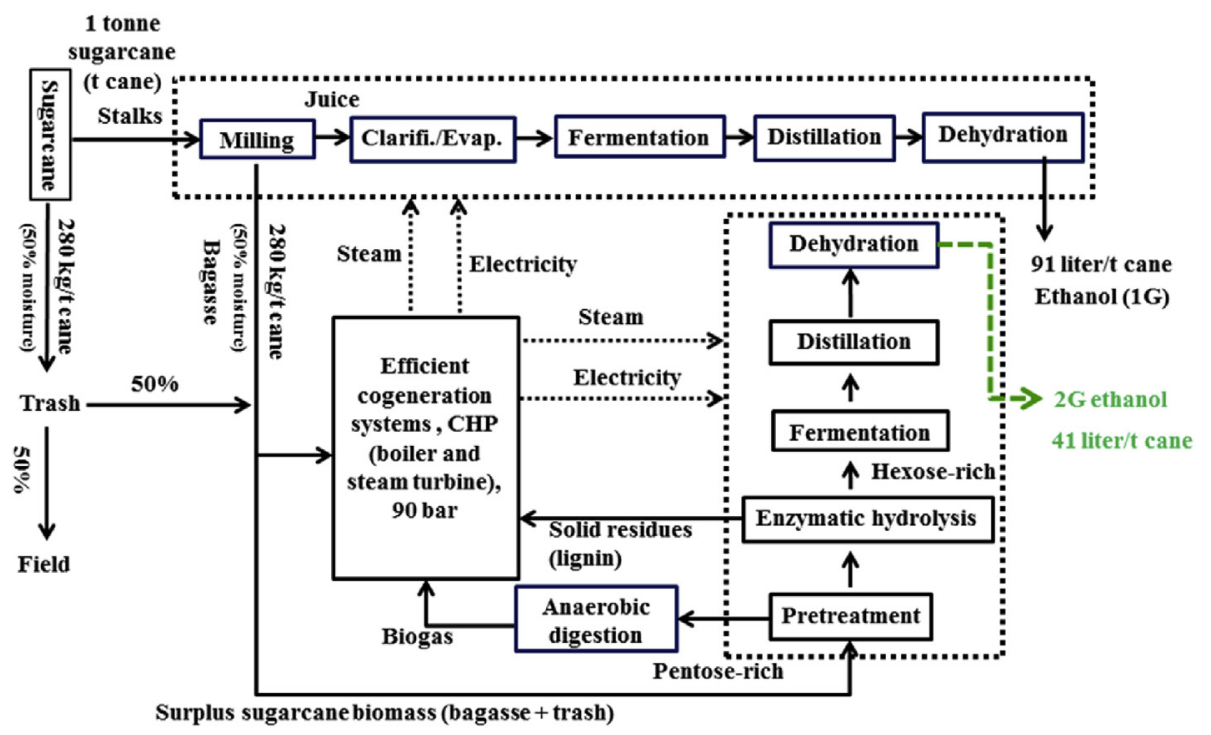

Fig. 3. Biochemical conversion of sugarcane biomass into ethanol - a schematic diagram.

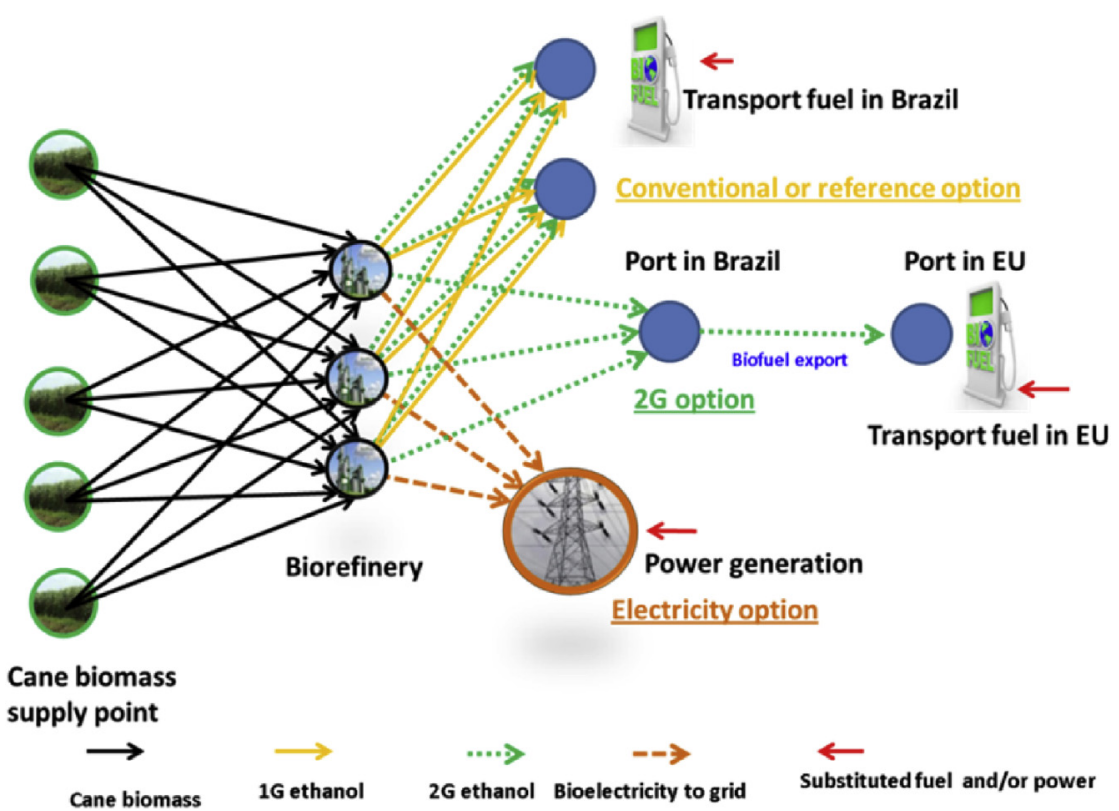

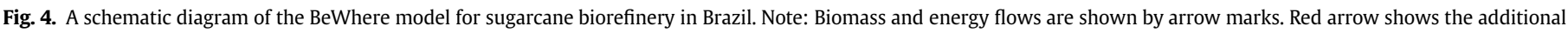
fossil fuel needed to meet the demand. (For interpretation of the references to colour in this figure legend, the reader is referred to the web version of this article.)

(CHP) or second generation biofuel production in Europe [39,49] and technology mix (methanol and CHP) of bioenergy production in Finland [38] were identified, considering the costs of the whole supply chain and different policy scenarios (e.g. carbon cost and biofuel support).

The model considers the processing of sugarcane feedstock (stalks and trash/residues) for energy services in the state of Sao Paulo (SP). The study region is divided into grid cells with a $0.1^{\circ}$ spatial resolution (approx. $10 \times 10 \mathrm{~km}$ ). All sugarcane mills that fall under a single grid cell are considered together as one, resulting in a total of 158 sugarcane biorefineries in the whole state. As mentioned earlier, the study considers that ethanol produced from sugarcane juice ( $1 \mathrm{G}$ ethanol) through fermentation is domestically consumed in Brazil. This analysis finds the most optimal pathways in the conversion of sugarcane biomass into the second generation
(2G) ethanol and/or bioelectricity using the available surplus bagasse in sugarcane mills and residual biomass (tops/leaves or trash) collected from the sugarcane field. The second generation $(2 \mathrm{G})$ ethanol, if produced, can be either be consumed in Brazil or exported to the EU depending on market and technological parameters. Bioelectricity produced is fed into the grid and utilized in Brazil. The model does not consider the dynamics of the sugarcane expansion and new sugarcane biorefineries, but incorporates existing sugarcane mills that would be upgraded for increased production of energy services, utilizing excess bagasse and trash/ residues. The size and location of the existing sugarcane mills are obtained from two different sources, UNICA [4] and Sugarcane Technology Center [50], respectively. Fig. 5 shows the size and location of the sugarcane mills. Distances between all the grid points of the existing sugarcane mills are computed using the GIS 


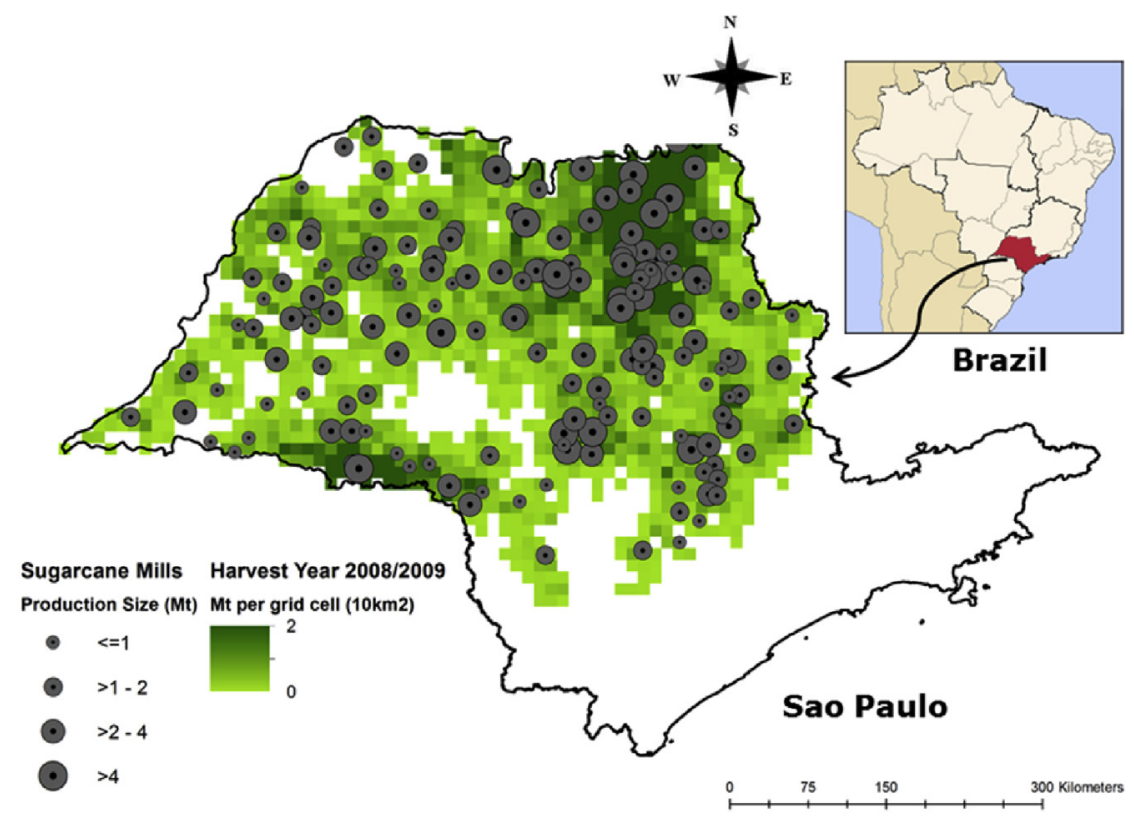

Fig. 5. Size and location of existing sugarcane mills in the state of Sao Paulo (SP), Authors' projection using data from Refs. [4,50].

software. The distance is used for estimating costs and emissions related to transport of sugarcane feedstock between sugarcane fields and plants.

The objective function is to minimize the total cost $\left(C_{\text {total }}\right)$ in the supply chain, which is expressed as

$\mathrm{C}_{\text {total }}=\mathrm{C}_{\text {supplychain }}+\mathrm{E}_{\text {supplychain }} \cdot \mathrm{C}_{\mathrm{CO}_{2} \text { eq }}$

where $C_{\text {supplychain }}$ is the supply chain cost, $E_{\text {supplychain }}$ is the supply chain emissions, and $\mathrm{C}_{\mathrm{CO} \text { eq }}$ is the cost for emitting GHG emissions.

The supply chain cost $\left(\mathrm{C}_{\text {supplychain }}\right)$ consists of: feedstock (sugarcane and trash) cost and transportation cost (to the production plant), investment and production costs, biofuel transport cost to specified supply points, fossil fuel (i.e. gasoline) cost for transport, and income from the sale of bioelectricity. Note that biofuel is transported to gas stations within the state of Sao Paulo (SP) and/or to the port (Rotterdam/the Netherlands) in the EU via the port of Santos located in the state of SP. The cost of gasoline in Brazil and in the EU is different.

The supply chain emissions ( $E_{\text {supplychain }}$ ) include: Emissions from sugarcane production/agriculture practices, emissions from sugarcane/trash transport, emissions from plant operations, emissions from biofuel transport, and avoided emissions from substituted fossil based transport fuel (in Brazil and the EU) and fossil based electricity. In the optimization model, carbon tax is applied to the GHG emissions $\left(\mathrm{CO}_{2 \mathrm{eq}}\right)$ associated with production chains of advanced conversion technologies, viz. electricity option (efficient cogeneration) and $2 \mathrm{G}$ ethanol option (biochemical conversion of sugarcane biomass), including emissions savings from potential substitutions of fossil based electricity or transport fuel.

The total cost is minimized subject to a number of constraints related to feedstock supply, operation balance in production plants, biofuel trade, and energy demand, see Refs. $[47,48]$ for the mathematical expression on how to formulate the objective function and constraints. The model inputs are: feedstock availability, size and location of the existing plants, transportation distance, annualized costs, emission factors, carbon tax, plant efficiencies, and prices of fuel and power. The model solves the problem by selecting the least costly technological option, considering the whole supply chain cost, emissions, and prices. Thus it does not optimize the profit of a single biorefinery, but rather considers the entire system for the welfare of the region. The resulting model output includes: the choice of technological option, supply chain costs and emissions, the share of $2 \mathrm{G}$ ethanol and bioelectricity, and amount of biofuel

Table 3

Investment costs of sugarcane biorefinery (MUS\$).

\begin{tabular}{|c|c|c|c|}
\hline \multirow{3}{*}{ Components } & \multicolumn{3}{|l|}{ Technological options ${ }^{\mathrm{a}}$} \\
\hline & \multirow[t]{2}{*}{ Conventional technology } & \multicolumn{2}{|l|}{ Upgraded } \\
\hline & & Electricity option & 2G ethanol option \\
\hline Juice extraction & 22.5 & 22.5 & 22.5 \\
\hline Juice treatment, fermentation and distillation and dehydration ${ }^{c}$ & 35.7 & 35.7 & 35.7 \\
\hline Cogeneration & 45.0 & 83.7 & 51.9 \\
\hline Automation, buildings etc. & 57.0 & 57.0 & 74.0 \\
\hline $2 \mathrm{G}$ ethanol conversion ${ }^{\mathrm{d}}$ & - & - & 102.0 \\
\hline Total investment (MUS\$) & 160.2 & 198.9 & 286.1 \\
\hline
\end{tabular}

a Processing capacity considered is 2 Mt cane per year.

b Costs are adopted from Ref. [9] and a scaling factor 0.7 is used, when necessary.

c Molecular sieves for ethanol dehydration is used.

d Investment costs for $2 \mathrm{G}$ ethanol option is considered to be 326 MUS\$/million tonne (Mt) dry sugarcane biomass (bagasse and trash), including 13 MUS\$ for pentose biodigestion in the 2 Mt capacity plant. Bonomi (2012) has presented the costs as 326 US\$/t-dry bagasse [55]. 
export. Notice that the study ignores the export of ethanol outside the EU and production of sugarcane bioenergy outside the Sao Paulo region in Brazil. Additionally, the study considers only two advanced conversion technologies i.e. efficient cogeneration plant and biochemical pathway via enzymatic hydrolysis. The technoeconomic performance of the production of commercial bioenergy from the thermochemical route (i.e. pyrolysis/gasification) has not been considered in the analysis.

\subsection{Data sources}

\subsubsection{Systems costs}

The supply chain costs for producing energy products in the sugarcane biorefinery are divided into two categories: (a) mass or volume based fixed costs (i.e. feedstock cost, investment and operation costs) which depend upon the amount of feedstock processed and the type of conversion technologies, and (b) distance-dependent feedstock and biofuel transport costs which are determined by the mode of transport and distance traveled.

The investment costs for the conventional and upgraded technologies are presented in Table 3. Note that the costs for the juice ethanol (1G) production are the same for all technologies. The capacity of each base plant is 2 Mt sugarcane processed per year (see Table 1). The size of existing sugarcane mills in the state of Sao Paulo varies between 0.1 and $8 \mathrm{Mt}$ cane per year [4] and the average output of the mills was $2 \mathrm{Mt}$ of cane crushed per year in the year 2010-2011 [51]. The costs of biomass conversion technologies have scaling effects [52]. Thus, in order to incorporate or adjust the investment costs of equipment depending upon the size of sugarcane biorefinery, a scaling factor $(\mathrm{R})$ is used, which is expressed as:

$$
\frac{\text { Cost }_{a}}{\text { Cost }_{\text {base }}}=\left(\frac{\text { Size }_{a}}{\text { Size }_{\text {base }}}\right)^{R}
$$

where Cost $_{a}$ and Size $_{a}$ represent the costs and capacity (Mt cane/ year) of the equipment of the new plant respectively while Cost $_{\text {base }}$

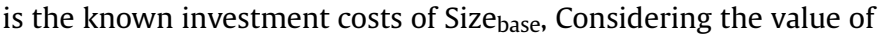
$\mathrm{R}$ as $\mathbf{0 . 7}$, the investment costs for different biorefinery sizes can be determined [53,54].

Further, investment costs of plants are annualized considering 25 years economic lifetime for the plant and an interest rate of $10 \%$ using Equation (3).

$A C=\frac{I R}{1-1 /(1+I R)^{t}} \cdot T I C$

where AC is the annualized cost, IR is the interest rate, TIC is the total investment costs, and $t$ is the economic lifetime.

The annualized costs and operation \& maintenance costs such as spare parts, enzyme costs are summarized in Table 4. It should be noted that operation and maintenance costs increase or decrease proportionately while investment costs are adjusted exponentially as the size of the biorefining options varies. The conversion efficiencies are assumed to be constant for all sizes of biorefineries. Fig. 6 shows the costs and production efficiencies of biorefineries estimated per Mt cane plant capacity. In order to see the effect of investment and operation costs (especially enzyme cost in the $2 \mathrm{G}$ ethanol option), a sensitivity analysis is performed.

Fixed costs for the feedstock and distance-dependent costs for the feedstock and biofuel transport are presented in Table 5. The average cost of sugarcane is 25 US\$/t cane and the cost of trash is 15 US\$/t-dry. The total costs of trash include: windowing, baling, bale loading, trailer towing, bale transportation and bale uploading [5]. Here, the cost of bale transportation is separately considered as distance-dependent. Costs are estimated for the year 2010 considering the inflation rate in Brazil. As currency conversion between the US dollar (US\$) and Brazilian Real dollar (R\$) has significantly varied, in a range of $1.5-2.9$ (US\$: R\$), during the last ten years, we consider the average conversion factor of the selected database year, including the year 2010 .

In Brazil, the sugarcane is priced according to its Total Recoverable Sugar (TRS). The expression is: sugarcane price (R $\$ / t)=$ TRS price (R $\$ / \mathrm{kg}$ of TRS) x Sugarcane quality ( $\mathrm{kg}$ of TRS/t of sugarcane). The price of TRS is determined both by sugarcane producers and buyers based on the cost of production of sugarcane as well as the prices of ethanol and sugar, aiming at equitable distribution of profits among the producers and buyers [4].

A network map of roads is used to estimate transportation routes and distance between the sugarcane farms and biorefinery plants, as well as between biorefineries and demand areas in Sao Paulo. Distribution of biofuel outside the state of Sao Paulo is not

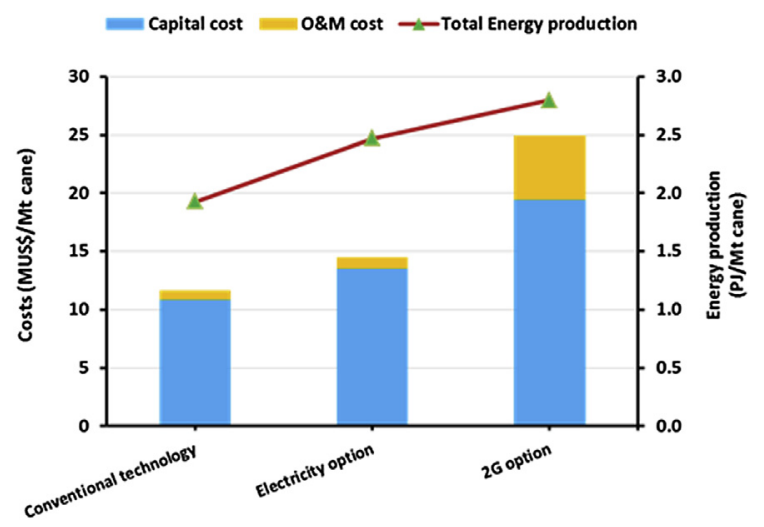

Fig. 6. Production costs and energy production per million tonne (Mt) cane.

Table 4

Annualized investment and O\&M costs of biorefineries (MUS\$).

\begin{tabular}{|c|c|c|c|}
\hline \multirow{3}{*}{ Items } & \multicolumn{3}{|l|}{ Technological options } \\
\hline & \multirow{2}{*}{ Conventional technology } & \multicolumn{2}{|l|}{ Upgraded } \\
\hline & & Electricity option & $2 \mathrm{G}$ ethanol option \\
\hline Annualized investment & 17.7 & 21.9 & 31.5 \\
\hline Working capital, @5\% & 0.9 & 1.1 & 1.6 \\
\hline Start-up costs, @3\% & 0.5 & 0.7 & 0.9 \\
\hline Spare parts, @1\% & 0.2 & 0.2 & 0.3 \\
\hline Cost of enzyme (for $2 \mathrm{G}$ ) & - & - & 8.2 \\
\hline
\end{tabular}

Notes: processing capacity considered is 2 million tonnes (Mt) per year.

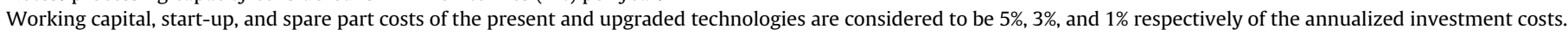
Enzyme price for $2 \mathrm{G}$ ethanol option is assumed to be $0.1 \mathrm{US} \$ / \mathrm{L}$ of $2 \mathrm{G}$ ethanol. 
Table 5

Fixed and distance-dependent costs of feedstock and biofuel.

\begin{tabular}{|c|c|c|}
\hline Parameter & Values & Units \\
\hline \multicolumn{3}{|l|}{ Costs of feedstock } \\
\hline Cost of sugarcane ${ }^{a}$ & 25 & US\$/t cane \\
\hline Cost of bagasse $^{\mathrm{b}}$ & 0 & $\mathrm{US} \$ / \mathrm{t}_{\mathrm{dry}}$ \\
\hline Cost of trash ${ }^{c}$ & 15 & $\mathrm{US} \$ / \mathrm{t}_{\mathrm{dry}}$ \\
\hline \multicolumn{3}{|l|}{ Costs of feedstock transport } \\
\hline Sugarcane transport cost $\mathrm{d}^{\mathrm{d}}$ & 0.32 & US\$/t-km \\
\hline Trash transport cost $\mathrm{t}^{\mathrm{e}}$ & 0.35 & $\mathrm{US} \$ / \mathrm{t}_{\mathrm{dry}}-\mathrm{km}$ \\
\hline \multicolumn{3}{|l|}{ Costs of biofuel transport } \\
\hline Truck $^{\mathrm{f}}$ & 5.56 & $\mathrm{US} \$ / \mathrm{km}-\mathrm{TJ}$ \\
\hline Ocean tanker ${ }^{g}$ & 0.49 & $\mathrm{US} \$ / \mathrm{km}-\mathrm{TJ}$ \\
\hline
\end{tabular}

a Sugarcane final price for the harvest year (2009/10) is considered which is 46.36 (R\$/t cane) i.e. 25 (US\$/t cane), See Ref. [4].

$\mathrm{b}$ The cost of bagasse is considered to be zero since it is an industrial residue that is already available free at suitable conditions in sugarcane mills [26].

c Trash biomass cost is taken from Ref. [5]. The initial US\$ value (for the year 2004) is converted into R\$, and inflation rate is applied. Finally, the cost is presented in US\$ for the year 2010. Average exchange rate for the particular year is considered.

d The cost of sugarcane transport from field to refinery is $\mathrm{R} \$ 6.7$ per $\mathrm{t}$ cane and an average distance from the farm to the mill is $22 \mathrm{~km} \mathrm{[56].} \mathrm{We} \mathrm{consider} \mathrm{the} \mathrm{two-way}$ transport.

e Trash transport cost is taken from Ref. [5] and adjusted for the year 2010, considering the inflation rate and the average currency conversion factor. Note that the amount of trash collected/transported is only $7 \%$ (dry mass) per $t$ cane.

f The cost of ethanol transport from the refinery to the port by truck is $\mathrm{R} \$ 49$ per $\mathrm{m}^{3}$ and average transportation distance is $499 \mathrm{~km}$ in 2006 [56]. The cost in US\$/ $\mathrm{km}$ $\mathrm{TJ}$ (in 2010) is estimated considering the inflation rate, average conversion factor, and two-way travel.

${ }^{g}$ Ethanol is transported by ocean tankers from the port in Sao Paulo/Brazil to the port of Rotterdam in EU. The cost of ethanol transport by the ocean tanker is given by Ref. [56], i.e. $\mathrm{R} \$ 103$ per $\mathrm{m}^{3}$. Our cost estimate is $0.49 \mathrm{US} \$ / \mathrm{km}-\mathrm{T}$ J, considering the inflation rate and round-trip travel.

considered. In this study, heavy-duty diesel trucks are used for the transportation of feedstock (sugarcane and trash). Bioethanol within Brazil is also transported using the same diesel trucks while the export of ethanol is done by means of ocean tankers. Note that ethanol pipelines as an alternative transportation mode are not considered.

\subsubsection{Lifecycle GHG emissions}

In this analysis, lifecycle GHG emissions in the biofuel supply chain are evaluated. The main GHGs considered are: carbon dioxide $\left(\mathrm{CO}_{2}\right)$, methane $\left(\mathrm{CH}_{4}\right)$, and nitrous oxide $\left(\mathrm{N}_{2} \mathrm{O}\right)$, which are converted to $\mathrm{CO}_{2}$ equivalent (i.e. $\mathrm{CO}_{2 \mathrm{eq}}$ ) by using Global Warming
Potential (GWP) of 1, 25 and 298, respectively [57]. Emissions from (a) feedstock production and processing, (b) transport of feedstock and biofuel, and (c) substituted fossil energy carriers are considered. The cost of emitting the total GHG emissions (i.e. $\mathrm{CO}_{2 \text { eq }}$ tax) is internalized in the model.

We account the direct GHG emissions from the following activities: (a) sugarcane farming, (b) agriculture inputs production, (c) field emissions, (d) feedstock processing, and (f) feedstock/biofuel transportation. GHG emissions (i.e. $\mathrm{CH}_{4}$ and $\mathrm{N}_{2} \mathrm{O}$ ) from the combustion of biomass in the biorefinery are also considered. $\mathrm{CO}_{2}$ emissions associated with biomass combustion are not accounted for since bioenergy is carbon-neutral along the biofuel chain. Emissions from embodied energy in plant and equipment are not considered. Direct and Indirect land use change (iLUC) effects are not in the scope of the analysis either since surplus sugarcane biomass (e.g. bagasse and trash) will only be used for bioenergy production without considering the expansion of sugarcane fields. However, the inclusion of indirect land use change (iLUC) can significantly affect the lifecycle greenhouse gas (GHG) emissions when it comes to the expansion of biomass/feedstock cultivation areas [58].

GHG emissions from feedstock production (sugarcane cultivation, field emissions, etc.) and feedstock processing for energy production are given in Table 6.

GHG emissions from feedstock and biofuel transport are shown in Table 7. Round-trip travel is considered. Transportation distance of feedstock and biofuel transport within Brazil varies but it is kept constant for the biofuel export from Sao Paulo to the EU port. Emission factors for fuel combustion are taken from the GREET model [60].

Avoided GHG emissions occur due to substitution of fossil fuel (i.e. gasoline) in road transport. Bioelectricity is assumed to displace marginal electricity (i.e. natural gas power) in the national grid in Brazil, instead of average electricity (mainly hydropower). However, we perform a sensitivity analysis considering a range of electricity produced from average to carbon intensive or fossil based electricity, e.g., coal power. Note that coal power is not common in Brazil but it serves as reference for other regions. Emission factors adopted in the model are presented in Table 8. Gasoline substituted is estimated considering energy equivalence (in 1:1 energy ratio) between gasoline and bioethanol, meaning that each GJ of biofuel substitutes $83.8 \mathrm{~kg}$ of $\mathrm{CO}_{2 \mathrm{eq}}$, taking the lifecycle emission factor of gasoline from the EU's Renewable

Table 6

GHG emissions in feedstock production and processing $\left(\mathrm{kgCO}_{2 \mathrm{eq}} / \mathrm{t}\right.$ cane $)$ in Brazil.

\begin{tabular}{|c|c|c|c|}
\hline Particulars & Conventional technology & Electricity option & $2 \mathrm{G}$ ethanol option \\
\hline Feedstock production & 34.7 & 32.1 & 32.1 \\
\hline Sugarcane farming ${ }^{\mathrm{a}}$ & 11.7 & 11.7 & 11.7 \\
\hline Agricultural inputs production ${ }^{\mathrm{a}}$ & 6.5 & 6.5 & 6.5 \\
\hline Trash burning ${ }^{\mathrm{b}}$ & - & - & - \\
\hline Field emissions ${ }^{c}$ & 16.5 & 13.9 & 13.9 \\
\hline Feedstock processing ${ }^{\mathrm{d}}$ & 5.6 & 7.5 & 7.8 \\
\hline Total emissions & 40.3 & 39.6 & 39.9 \\
\hline
\end{tabular}

${ }^{a}$ GHG emisisons from sugarcane farming and agriculture inputs production are $6.8 \mathrm{gCO}_{2 \mathrm{eq}} / \mathrm{MJ}_{\text {and }} 3.8 \mathrm{gCO} \mathrm{geq}_{2} / \mathrm{MJ}_{(\text {anhydrous ethanol) respectively, i.e., } 11.7 \mathrm{kgCO}} \mathrm{q} / \mathrm{t}$ cane and $6.5 \mathrm{kgCO}_{2 \mathrm{eq}} / \mathrm{t}$ cane, considering ethanol yield as $81.1 \mathrm{~L} / \mathrm{t}$ cane [59].

b Trash burning practices are assumed to be eliminated.

c Field emissions represent emissions from the soil due to fertilizers, industrial residues (returned to the soil), and limestone application. Total unburnt trash (dry kg/t cane)

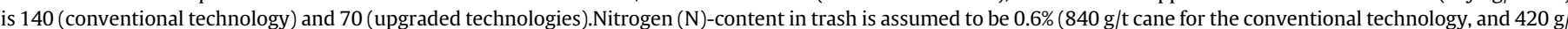

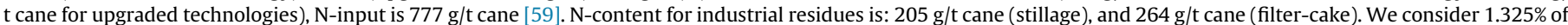

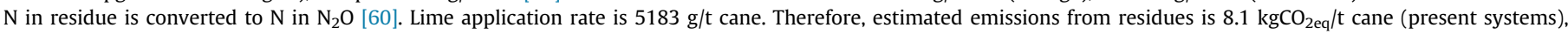
$5.5 \mathrm{kgCO}_{2 \mathrm{eq}} / \mathrm{t}$ cane (upgraded systems), and fertilizer application: $8.3 \mathrm{kgCO}_{2 \mathrm{eq}} / \mathrm{t}$ cane (i.e. nitrogen: $6.1 \mathrm{kgCO} \mathrm{Ceq}_{2}$ and lime: $2.3 \mathrm{kgCO}$ eq $/ \mathrm{t} \mathrm{cane)}$.

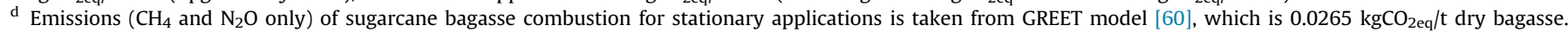

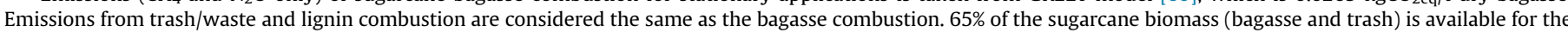

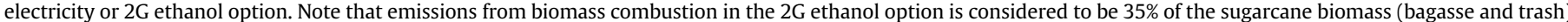

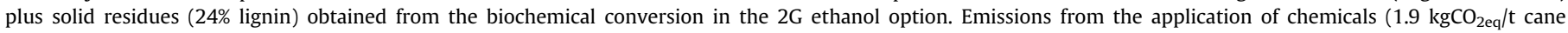
considering juice or $1 \mathrm{G}$ ethanol [61] and enzyme (3.6 $\mathrm{kgCO}_{2 \mathrm{eq}} / \mathrm{MJ}_{2 \mathrm{G}}$ ethanol [62] or $3.125 \mathrm{kgCO} \mathrm{geq}_{\text {eq }}$ normalized per t cane) are also considered in the estimation. 
Table 7

Emissions from feedstock and biofuel transport. ${ }^{a}$

\begin{tabular}{lcl}
\hline Parameter $^{\mathrm{b}}$ & Values & Units \\
\hline Emissions from feedstock transport $^{\mathrm{c}}$ & 112.2 & $\mathrm{tCO}_{2 \mathrm{eq}} / \mathrm{Mt}-\mathrm{km}$ \\
Emissions from biofuel transport (Truck) $^{\mathrm{d}}$ & 5.18 & $\mathrm{tCO}_{2 \mathrm{eq}} / \mathrm{km}-\mathrm{PJ}$ \\
Emissions from biofuel transport (Ocean tanker) $^{\mathrm{e}}$ & 0.14 & $\mathrm{tCO}_{2 \mathrm{eq}} / \mathrm{km}-\mathrm{PJ}$ \\
\hline
\end{tabular}

${ }^{a}$ Round-trip travel is considered. We consider road transportation using heavyduty trucks.

b Emission factors (grams per MJ of fuel burned) of fuel combustion (feedstock and fuel transportation) are considered from GREET model [60], i.e. $86.2 \mathrm{gCO}_{2 \mathrm{eq}} / \mathrm{MJ}$ (for heavy duty truck) and $85.8 \mathrm{gCO}_{2 \mathrm{eq}} / \mathrm{MJ}$ (for diesel ocean tanker). Energy content of ethanol (LHV) is $26.8(\mathrm{MJ} / \mathrm{kg})$.

c One-way transportation distance and truck efficiency for sugarcane transport are considered as $21 \mathrm{~km}$ and $55 \mathrm{t} \mathrm{km} / \mathrm{L}$, respectively [61].

d Emissions from ethanol transport (road) is $3.4 \mathrm{kgCO}_{2 \mathrm{eq}} / \mathrm{t}$ cane, a total transportation distance is assumed to be $340 \mathrm{~km}$ [61]. Emissions from the trash transport are considered to be the same as that of sugarcane transport. Note that amount of trash transported is $70 \mathrm{~kg}$-dry per $\mathrm{t}$ cane.

e The value of energy intensity is $0.02 \mathrm{MJ} / \mathrm{t}-\mathrm{km}$ in the ocean tanker transport [64].

Table 8

Emission factors for fossil fuel based energy $\left(\mathrm{kgCO}_{2 \mathrm{q}} / \mathrm{GJ}\right)$.

\begin{tabular}{lc}
\hline Gasoline $^{\mathrm{a}}$ & 83.8 \\
Electricity $^{\mathrm{b}}$ & 160 \\
Electricity (natural gas) & 280 \\
Electricity (Coal) & \\
\hline
\end{tabular}

a EU's Renewable Energy directive [63]. It is considered that emissions factor for gasoline is the same in Brazil and the EU.

b Marginal electricity in Brazil is considered to be natural gas power [59]. Sensitivity analysis is performed in a range of $70 \mathrm{kgCO}_{2 \mathrm{eq}} / \mathrm{GJ}$ (average) to $280 \mathrm{kgCO}_{2 \mathrm{eq}} / \mathrm{GJ}$ (Coal). Note that Seabra and Macedo (2011) use a range of electricity emission factor from 400 to $1000 \mathrm{kgCO}_{2 \mathrm{eq}} / \mathrm{MWh}$ (i.e. about $110-280 \mathrm{kgCO}_{2 \mathrm{eq}} / \mathrm{GJ}$ ) for analyzing avoided emissions [6].

\section{Energy Directive 2009/28/EC [63].}

\subsubsection{Energy prices and fuel demand}

\section{a. Energy prices:}

Prices for energy in transport and electricity markets highly affect the suitability of sugarcane energy products. Prices have fluctuated drastically in the last few years, especially for fossil based energy [65]. Table 9 presents the energy prices of transport fuel in Brazil and the EU, and electricity in Brazil in 2010. These are the retail prices. Note that the model considers the price of pure gasoline which is supposed to be substituted by the use of anhydrous ethanol. Sensitivity analysis is performed to include a wide range of price variation in the European and Brazilian markets.

\section{b. Demand of biofuel and bioelectricity}

The share of ethanol in the Otto-cycle vehicle was $55 \%$ in the state of Sao Paulo and 40\% in Brazil as a whole in 2010. The projected amount of bioethanol consumption in Brazil is 64.6 billion liters (i.e.1370 $\mathrm{PJ} \mathrm{y}^{-1}$ ), resulting in a $66 \%$ share by 2020 [67]. The internal demand of bioethanol in Brazil can be approximately met by first generation ethanol when the sugarcane production is just doubled, which is likely to happen, according to [4]. In fact, sugarcane production has grown at an average rate of $10.5 \%$ rate per year since 2000 (till 2009/10) in Brazil.

Meanwhile, the government of Brazil is making efforts to increase production of bioelectricity from sugarcane biomass (bagasse and trash). With the use of efficient cogeneration plants, sugarcane mills can provide $20 \%$ of the total electricity production
Table 9

Reference prices of transport fuel and electricity ${ }^{\mathrm{a}}$.

\begin{tabular}{lll}
\hline Parameters & Values & Units \\
\hline Gasoline price (gasoline A) in Brazil $^{\mathrm{b}}$ & 50 & US\$/GJ \\
Gasoline price (95 RON) in the EU $^{\mathrm{c}}$ & 65 & US\$/GJ \\
Electricity price in Brazil $^{\mathrm{d}}$ & 55 & US\$/GJ \\
\hline
\end{tabular}

a Retail prices are considered for both gasoline and electricity in Brazil and the EU. The retail price of electricity represents the actual price of end-use electricity service in Brazil whereas auction prices, which are lower than the retail prices only indicate the gate prices. In the study, the retail prices are used for the modeling purpose. Sensitivity analysis is also performed taking into account a range of the prices.

b Pure gasoline (or Gasoline A) is not sold at the gas station in Brazil. Instead, gasoline $\mathrm{C}$, which is the blend of $25 \%$ anhydrous ethanol and $75 \%$ gasoline A) by volume, is used. Thus, the price of Gasoline A is estimated by the formula: "(Gasoline C price - $(0.25 \times$ Anhydrous ethanol price $)) / 0.75$ ". Note that the average retail prices of gasoline $C$ and anhydrous fuel ethanol in 2010 were 2.46 and $1.52 \mathrm{R} \$ / \mathrm{L}$, respectively. Prices of gasoline $C$ and anhydrous ethanol are obtained from Ref. [4]. Gasoline A price is expressed in US\$/GJ. Energy value (LHV) for the pure gasoline is $32.2 \mathrm{MJ} / \mathrm{L}$.

c Average price of unleaded petrol (95 RON) in the EU is considered to be $1.5 € / \mathrm{L}$. d Electricity retail price in the residential sector is considered, which is assumed to $370 \mathrm{R} \$ / \mathrm{MWh}$ (i.e. 55 US\$/GJ) for the year 2009/10. Note that the regulatory agency, the Brazilian Electricity Regulatory Agency (Portuguese acronym: ANEEL), fixes the electricity tariff considering the economic/financial balance in each concession area (i.e. covering operating costs and adequate return on the capital invested), see Ref. [66].

in Brazil [21]. As mentioned earlier, in order to diversify energy products derived from the residual biomass in sugarcane biorefineries, the production of second generation (2G) ethanol is also being promoted but still in the phase of development.

In the EU, as part of the Renewable Energy Directive (2009/28/ EC), a minimum target share of $10 \%$ renewables (mainly biofuel) should be reached in the transport sector by 2020 [63]. Previously, a target of $5.75 \%$ by 2010 was set by the EU for the share of biofuels in petrol and diesel [68], but the percentage of total biofuel use in the EU member states (EU-27) only reached $4.7 \%$ in 2010 [69]. The consumption of biofuel in the EU-27 was $558 \mathrm{PJ} \mathrm{y}^{-1}$, consisting of $21 \%$ bioethanol and $79 \%$ biodiesel in 2010 . To meet the target of $10 \%$ by $2020,1461 \mathrm{PJ} \mathrm{y}^{-1}$ biofuel is required [68]. Second generation bioethanol from sugarcane biomass in Brazil can contribute towards this goal.

\subsection{Scenarios and sensitivity analysis for upgraded technological options}

We developed different scenarios for the two upgraded technological options: bioelectricity and $2 \mathrm{G}$ ethanol. The influencing model parameters are identified and further scrutinized. Investment and operation costs of $2 \mathrm{G}$ ethanol option are high compared to the electricity option. The investment cost and enzyme cost are, therefore, worth closer examination. The study examines the effect of the costs of emitting GHG emissions (i.e. carbon tax), biofuel policy support (such as tax reduction and green certificates), plant efficiencies, and the price or cost of energy services.

Table 10 shows the details of all scenarios developed. Each scenario is explicitly described. Scenario- 0 is the base or reference case that reflects the existing technological and market conditions, including current costs and prices as described in data inputs (Section 3.2). Bioelectricity produced in the biorefinery displaces natural gas power, which is the main contributor of the marginal electricity generation in Brazil [59].

The model is run and sensitivity analysis is performed, taking a range of input parameters. Parameters are incrementally varied in order to see their impact. The impacts of integrated or combined parameters are also dealt with. Biofuel support is applied separately in Brazil and in the EU. Higher gasoline price in the EU 
Table 10

\begin{tabular}{|c|c|c|c|c|c|c|c|c|c|c|c|}
\hline \multirow[t]{3}{*}{ Scenarios $^{\mathrm{a}, \mathrm{b}}$} & \multirow{3}{*}{$\begin{array}{l}\text { Electricity } \\
\text { price } \\
\text { US\$/GJ }\end{array}$} & \multirow{3}{*}{$\begin{array}{l}\text { Power plant } \\
\text { efficiency } \\
\text { improvement } \\
\text { (\%) }\end{array}$} & \multirow{3}{*}{$\begin{array}{l}\text { Emission } \\
\text { factor } \\
\text { (electricity) } \\
\mathrm{kgCO}_{2 \mathrm{eq}} / \mathrm{GJ}\end{array}$} & \multirow{3}{*}{$\begin{array}{l}\text { Investment } \\
\text { cost }(2 \mathrm{G})^{\mathrm{c}} \\
(\%)\end{array}$} & \multirow{3}{*}{$\begin{array}{l}\text { Enzyme } \\
\text { cost }(2 \mathrm{G}) \\
(\%)\end{array}$} & \multicolumn{2}{|c|}{ Gasoline price } & \multicolumn{2}{|c|}{ Biofuel support } & \multirow{3}{*}{$\begin{array}{l}\text { Carbon } \\
\operatorname{tax} \\
\text { US\$/tCO }\end{array}$} & \multirow[t]{3}{*}{ Scenario description } \\
\hline & & & & & & $\mathrm{EU}$ & Brazil & $\mathrm{EU}$ & Brazil & & \\
\hline & & & & & & \multicolumn{2}{|l|}{ US\$/GJ } & \multicolumn{2}{|l|}{ US\$/GJ } & & \\
\hline Sc-0 & 55 & - & 0.16 & - & - & 65 & 50 & 0 & 0 & 50 & $\begin{array}{l}\text { Reference or base case with existing conditions (e.g. } \\
\text { efficiencies, natural gas power as marginal } \\
\text { electricity), current costs and prices, carbon tax: } 50 \\
\text { US } \$ / \mathrm{tCO}_{2 \text { eq, }} \text { and no biofuel support. }\end{array}$ \\
\hline Sc-1 & $(55-80)$ & - & 0.16 & - & - & 65 & 50 & 0 & 0 & 50 & Electricity price varies between 55 and 80 US\$/GJ. \\
\hline Sc-2 & (80) & - & 0.16 & - & - & 65 & 50 & $(3-10)$ & 0 & 50 & $\begin{array}{l}\text { Electricity price is set at } 80 \text { US\$/GJ in Brazil, but } \\
\text { biofuel support (US\$/GJ) applied in the EU. }\end{array}$ \\
\hline Sc-3 & 55 & - & 0.16 & $(15-90)$ & - & 65 & 50 & 0 & 0 & 50 & $\begin{array}{l}\text { Total Investment cost of } 2 \mathrm{G} \text { ethanol option is } \\
\text { increased up to } 90 \% \text { while investments for the } \\
\text { current technology and electricity option are kept } \\
\text { constant. }\end{array}$ \\
\hline Sc-4 & 55 & - & 0.16 & - & $(150-400)$ & 65 & 50 & 0 & 0 & 50 & $\begin{array}{l}\text { Operation cost (i.e. cost of enzyme) for } 2 \mathrm{G} \text { ethanol } \\
\text { option is increased - up from } 150 \% \text { to } 400 \% \text {. }\end{array}$ \\
\hline Sc-5 & 55 & - & 0.16 & (100) & - & 65 & 50 & $(1-40)$ & 0 & 50 & $\begin{array}{l}\text { Investment cost of } 2 \mathrm{G} \text { ethanol option is increased by } \\
\text { two-fold but there exists biofuel support in the EU. }\end{array}$ \\
\hline Sc-6 & 55 & - & $(0.28)$ & - & - & 65 & 50 & 0 & 0 & $(70-150)$ & $\begin{array}{l}\text { Fossil based electricity (emission factor: } 0.28 \\
\mathrm{kgCO}_{2 \text { eq }} / \mathrm{MJ} \text { ) is considered as marginal electricity in } \\
\text { Brazil. Options are simulated at the varying carbon } \\
\text { tax rates (US\$ } \$ \mathrm{tCO}_{2 \text { eq }} \text { ). }\end{array}$ \\
\hline Sc-7 & 55 & $(0-35)$ & 0.16 & - & - & 65 & 50 & 0 & 0 & 50 & Power plant efficiency is increased up to $35 \%$. \\
\hline Sc-8 & 55 & (50) & 0.16 & - & - & 65 & 50 & $(6-15)$ & 0 & 50 & $\begin{array}{l}\text { Improved efficiency in power conversion is set at } \\
50 \% \text { while biofuel support (US\$/GJ) is provided in } \\
\text { the EU. }\end{array}$ \\
\hline Sc-9 & $(50-61)$ & - & 0.16 & - & - & $($ low, $<50)$ & 50 & 0 & 0 & 50 & $\begin{array}{l}\text { Price of fossil fuel is kept low ( }<50 \text { US\$ } \$ G J) \text { in the EU, } \\
\text { there will be no export of } 2 \mathrm{G} \text { ethanol, making } \\
\text { conflict between } 2 \mathrm{G} \text { ethanol and bioelectricity } \\
\text { within Brazil at the varying price of electricity. }\end{array}$ \\
\hline Sc-10 & (65) & - & 0.16 & - & - & (low, <50) & 50 & 0 & $(1-10)$ & 50 & $\begin{array}{l}\text { Gasoline price in the EU is kept less than } 50 \text { US\$/GJ, } \\
\text { electricity price in Brazil is set at } 65 \text { US\$/GJ while } \\
\text { biofuel support for } 2 \mathrm{G} \text { ethanol option, in a range of } 1 \\
-10 \text { US\$/GJ, is applied in Brazil. }\end{array}$ \\
\hline Sc-11 & 55 & - & 0.16 & $(0-25)$ & - & $($ low, $<50)$ & 50 & 0 & 0 & 50 & $\begin{array}{l}\text { Gasoline price in the EU is kept less than } 50 \text { US\$/GJ, } \\
\text { total investment cost of } 2 \mathrm{G} \text { ethanol option is } \\
\text { increased up to } 25 \% \text {, keeping investments for } \\
\text { reference technology and electricity option at the } \\
\text { reference level. }\end{array}$ \\
\hline Sc-12 & 55 & (50) & 0.16 & - & - & $($ low, $<50)$ & 50 & 0 & $(15-25)$ & 50 & $\begin{array}{l}\text { Gasoline price in the EU is kept less than } 50 \text { US\$/GJ, } \\
\text { power plant efficiency is increased up to } 50 \% \text { while } \\
\text { biofuel support is applied in Brazil. }\end{array}$ \\
\hline Sc-13 & 55 & - & $(0.09-0.28)$ & - & - & $($ low, $<50)$ & 50 & 0 & 0 & 50 & $\begin{array}{l}\text { Gasoline price in the EU is kept less than } 50 \text { US\$/GJ, } \\
\text { emission factor for substituted or displaced } \\
\text { electricity is varied from } 0.09 \text { to } 0.28 \mathrm{kgCO}_{2 \mathrm{eq}} / \mathrm{MJ} \text {. }\end{array}$ \\
\hline Sc-14 & 55 & - & 0.16 & - & - & $($ low, $<50)$ & 50 & 0 & 0 & $(75-275)$ & $\begin{array}{l}\text { Gasoline price in the EU is kept less than } 50 \mathrm{US} \$ / \mathrm{GJ} \text {, } \\
\text { natural gas power (emission factor: } 0.16 \mathrm{kgCO} \text {,eq } / \\
\mathrm{MJ} \text { ) is considered as marginal electricity in Brazil, } \\
\text { options are simulated at the varying carbon tax } \\
\text { rates ( } \mathrm{US} \$\left(\mathrm{tCO}_{2 \mathrm{eq}} \text { ) }\right.\end{array}$ \\
\hline
\end{tabular}

\footnotetext{
a Scenarios $1-8$ consider the current gasoline prices in the EU and Brazil.

b Scenarios 9-14 study the conflict between $2 \mathrm{G}$ ethanol and bioelectricity within Brazil, setting an unfavorable condition for ethanol export to the EU.
}

Investment costs refer to the total set-up costs (including upgraded systems costs) of the individual biorefinery. 
Table 11

Categorization of parameters and scenarios.

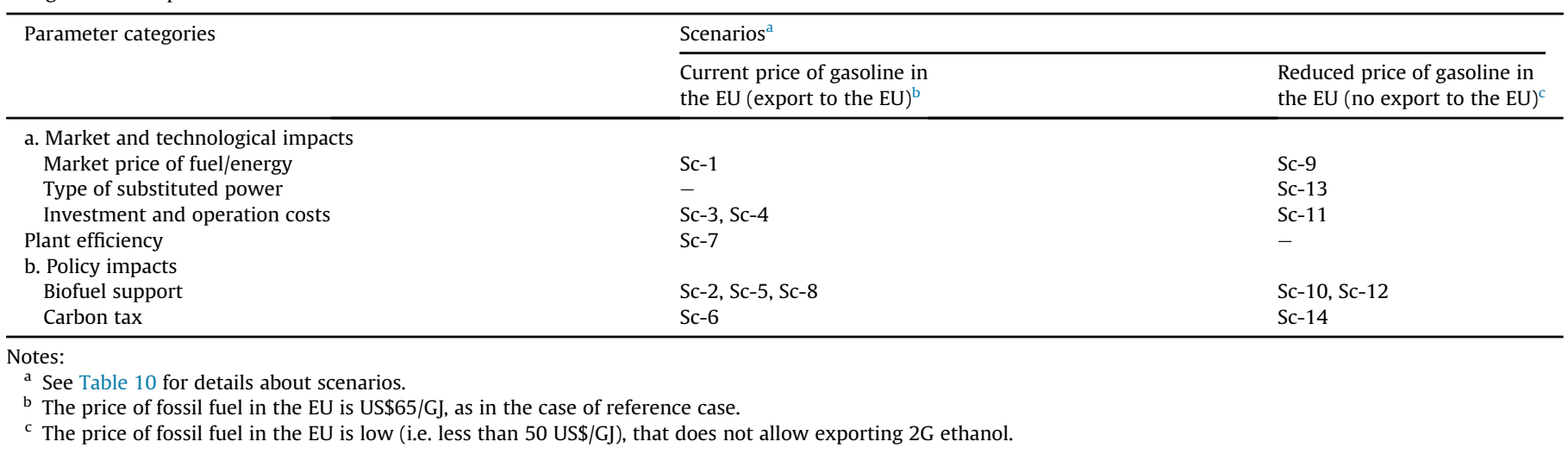

noticeably favors the export of the $2 \mathrm{G}$ ethanol from Brazil. Scenarios 1-8 examine the optimal choice between producing $2 \mathrm{G}$ ethanol and exporting to the EU and bioelectricity in Brazil. However, lower price of gasoline in the EU allows the use of $2 \mathrm{G}$ ethanol in Brazil, depending upon its competitiveness against bioelectricity. Scenarios 9-14 consider the analysis of $2 \mathrm{G}$ ethanol and/or bioelectricity option in Brazil.

\section{Results and discussions}

The study shows that it is worthwhile to upgrade sugarcane biorefineries for the production of more energy services in the form of second generation ( $2 \mathrm{G}$ ) ethanol and/or bioelectricity using residual sugarcane biomass. We discuss here the results obtained from the scenario analysis, particularly focusing on the factors that most influence the technological options.

\subsection{Reference scenario}

In the base or reference scenario Sc- 0 , in which present conditions apply, it is optimal to produce $2 \mathrm{G}$ ethanol in Brazil and export to the EU. Total $1 \mathrm{G}$ and $2 \mathrm{G}$ ethanol production is $668 \mathrm{PJ} \mathrm{y}^{-1}$ and $301 \mathrm{PJ} \mathrm{y}^{-1}$, respectively. The total lifecycle GHG emissions are estimated to be $16.8 \mathrm{Mt} \cdot \mathrm{CO}_{2 \mathrm{eq}} \mathrm{y}^{-1}$. The result indicates that $2 \mathrm{G}$ ethanol could amount to $2.5 \%$ of the EU transport fuel consumption in 2010, which is a significant share of contribution to the EU transport fuel mix. Fig. 7 shows the share of emissions and costs along the biofuel chain. Emissions from feedstock production correspond to the largest share of emissions along the fuel chain i.e. $66 \%$, followed by plant emissions (16\%), and feedstock transport (11\%). When it comes to costs feedstock cost contributes only $37 \%$ (see Fig. 7). The use of ethanol in transport will substitute gasoline and subsequently remove $55 \mathrm{Mt} . \mathrm{CO}_{2 \mathrm{eq}}$ in Brazil and $25 \mathrm{Mt} . \mathrm{CO}_{2 \mathrm{eq}}$ in the EU, thus resulting in $79.4 \%$ total emissions savings compared to conventional fossil fuel. The total cost of producing ethanol ( $1 \mathrm{G}$ and $2 \mathrm{G}$ ) is US $\$ 24.9 / \mathrm{GJ}$. The value is comparable to the cost of producing first generation $(1 \mathrm{G})$ ethanol in the US and Brazil. Note that the cost of corn ethanol production in the US (net of co-product credit) was US\$19.3/GJ and sugarcane juice ethanol in Brazil was US\$18.7-32.6/GJ in a range of 1.55-2.62 (US\$: R\$) currency conversion [56].

\subsection{Determining the impact of key parameters: scenario and sensitivity analysis}

The study finds that the main parameters influencing the choice of technological options are: electricity price, set-up and operation costs, type of marginal electricity substituted, power plant efficiency, gasoline price, and policy instruments (i.e. biofuel support and carbon tax). Results are obtained by varying individual parameters. It should be noted that a few scenarios (i.e. Sc 9-14) are also developed to study the choice of bioelectricity and/or 2G ethanol options within Brazil, limiting the export of $2 \mathrm{G}$ ethanol in the EU (see Table 10, Section 3.3). However, it is rather difficult to directly compare the results with the existing techno-economic optimization studies at the plant level in Brazil due to its scope of the study/systems boundary, inclusion of all biorefineries in the state of Sao Paulo, and policy impacts. Results of different scenarios are broadly divided into two categories: (a) technological and market impacts, viz., plant efficiency, investment and operation costs, type of substituted power, and market price of fuel/energy, and (b) policy impacts, i.e. biofuel support and carbon tax. Table 11 summarizes the impacts analyzed in the study, considering the parameter categories and conditions for exports or no exports of $2 \mathrm{G}$ ethanol to the EU.

\subsubsection{Influence of market and technological factors on the technological choice}

The impact of electricity price in Brazil is scrutinized in scenarios Sc-1 and Sc-9 with the base case and at the low fossil fuel price in the EU, respectively. Fig. 8(a) shows that the $2 \mathrm{G}$ ethanol option is left in favor of the electricity option when the price of electricity goes from 68 US\$/GJ in the base case to 76 US\$/GJ. At 72 US\$/GJ price, $41 \%$ of all sugarcane biorefineries select the electricity option and the others remain in the $2 \mathrm{G}$ ethanol option. The corresponding amount of energy products are $54 \mathrm{PJ}$ bioelectricity $(20 \%$ share) and 214 PJ second generation (2G) ethanol. Note that all plants would be converted into the bioelectricity production option at an electricity price of 76 US\$/GJ, which is $38 \%$ higher that the base case price.

Scenario Sc-9 considers the effect of the electricity price when the export of $2 \mathrm{G}$ ethanol is limited, by setting fossil fuel price low at 50 US $\$ / G$ in the EU, which makes the suitability analysis between $2 \mathrm{G}$ ethanol and electricity production in the energy systems in Brazil. The majority of biorefineries would opt for the electricity option when the price of electricity exceeds 60 US\$/GJ. Thus, if the system does not allow $2 \mathrm{G}$ ethanol exports, there is no strong support for producing $2 \mathrm{G}$ ethanol. A small increase (i.e. 9\%) in the electricity price is enough to motivate the electricity option, see Fig. 8(b). It is also verified that energy market prices of $2 \mathrm{G}$ ethanol and bioelectricity play a key role in determining economic performances of a flexible sugarcane biorefinery [30,31].

In the reference scenario (Sc-0), marginal electricity in Brazil is natural gas power (electricity emission factor: $0.16 \mathrm{kgCO}_{2 \mathrm{eq}} / \mathrm{MJ}$ ). 
Lifecycle costs

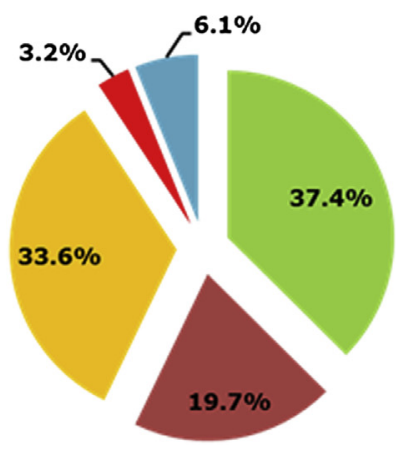

Emissions

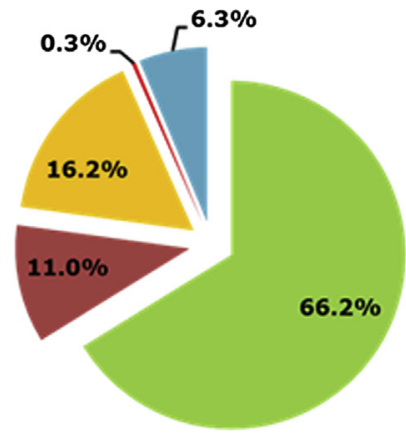

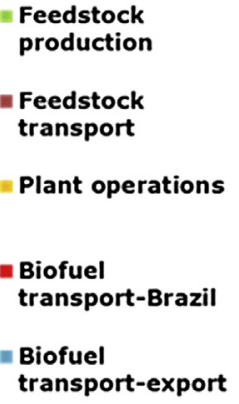

Fig. 7. Lifecycle costs (left) and emissions (right) along the biofuel supply chain (scenario Sc-0).

Even if the marginal electricity were carbon-intensive coal power (electricity emission factor: $0.28 \mathrm{kgCO}_{2 \mathrm{eq}} / \mathrm{MJ}$ ), it is optimal to produce $2 \mathrm{G}$ ethanol for export to the EU (Scenario Sc-6 at the base case $50 \mathrm{US} \$ / \mathrm{tCO}_{2 \mathrm{eq}}$ carbon tax). In contrast, with the case of no export of $2 \mathrm{G}$ ethanol to the EU (scenario Sc-13), electricity emissions factor i.e. type of marginal or substituted electricity would determine the choice of ethanol and/or electricity configuration (see Fig. 9). For example, high electricity emission factor $0.28 \mathrm{kgCO}_{2 \mathrm{eq}} / \mathrm{MJ}$ favors the production of electricity optimally.

The production of $2 \mathrm{G}$ ethanol is still in the phase of research and development. Therefore, it is likely that the investment and operation costs would increase in the future. The effect of increase in the $2 \mathrm{G}$ ethanol set-up cost and enzyme costs are performed in scenarios Sc-3, Sc-4 and Sc-11, keeping the investment costs of bioelectricity technology constant. Operation cost (mainly enzyme cost) does not have a high impact until its 3-fold increase at the reference condition. Furlan et al. (2013) also found that the impact of enzyme cost on the Internal Rate of Return (IRR) of a flexible sugarcane biorefinery was not significant [31]. However, investment costs have a significant role in determining the technological options with or without ethanol exports to the EU, see Fig. 10. For example, a $75 \%$ increase in the cost of the $2 \mathrm{G}$ option would convert $84 \%$ of sugarcane biorefineries into the electricity option if we consider the export of ethanol, see Fig. 10a. It is more sensitive with the condition of no export since $25 \%$ increase in the investment cost would prompt to select the electricity option (Fig. 10b). Of the total, 108 biorefineries will select the electricity option if the investment cost of $2 \mathrm{G}$ option increases $20 \%$.

In the reference scenario Sc-0, power plant efficiency is set at $150 \mathrm{kWh} / \mathrm{t}$ cane (i.e. $1.93 \mathrm{PJ} / \mathrm{Mt}$ cane). The technology considered is condensing-cum-extraction steam turbine (CEST). With the use of biomass integrated gasification combined cycle (BIG-CC) technology, electrical efficiency can be increased to more than $250 \mathrm{~kW} / \mathrm{t}$ cane (Khatiwada et al., 2012). In scenario Sc-7, the impact of plant efficiency is analyzed. The study finds that if conversion efficiency is increased by $35 \%$ (i.e. $202.5 \mathrm{kWh} / \mathrm{t}$ cane), all plants are selected to produce electricity optimally, see Fig. 11. However, biofuel support (i.e. incentives or subsidies) of 15 US $\$ / G J$ in the EU can create a shift towards the $2 \mathrm{G}$ option even if the conversion efficiency is doubled (Scenario Sc-8)

The study also reveals that the number of ethanol and/or electricity options selected and corresponding energy production are

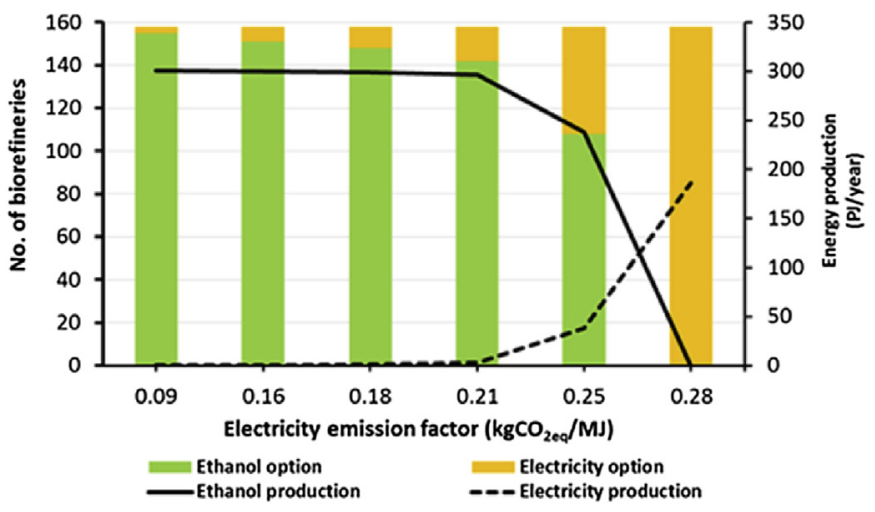

Fig. 9. Impact of the type of substituted electricity (Sc-13) (expressed in electricity emission factor) base case with no export of ethanol (i.e. low fossil fuel price in the EU).

\section{a. At the base case (Sc-1)}

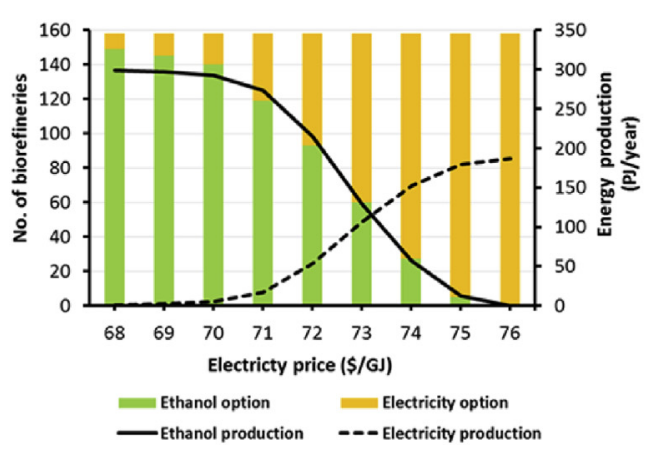

b. At the low fossil fuel price $(<50$ US\$/GJ) in the EU (Sc-9)

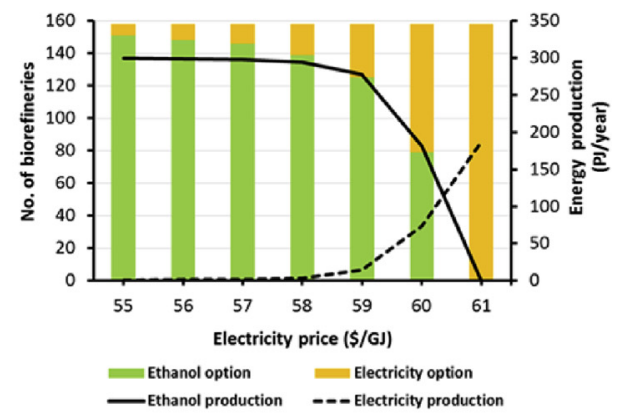

Fig. 8. Impact of the electricity price at the base case and low fossil fuel price conditions (Sc-1 and Sc-9). 
not proportionally related in all scenarios, mainly because of economies of scale. Biomass conversion technologies considered in this study, viz., condensing-cum-extraction steam turbine (CEST) based cogeneration plant for electricity option and biochemical conversion for second generation $(2 \mathrm{G})$ ethanol option are at different level of technological and commercial development. CEST is commercially available whereas $2 \mathrm{G}$ option is still in the phase of development. Therefore, it is important to simulate model results, considering technological improvements in terms of systems costs and conversion efficiency.

\subsubsection{Influence of policy on the technological choice}

The impacts of biofuel support and carbon tax policy instruments in both EU and Brazil are evaluated in various scenarios (see Table 11). As discussed earlier, when the price of electricity increases above 76 US\$/GJ, the model selects the electricity option (scenario Sc-1). However, biofuel support applied in the EU has the potential to make the $2 \mathrm{G}$ option optimally feasible (scenario Sc-2). Fig. 12(a) shows the extent to which biofuel support in the EU promotes $2 \mathrm{G}$ ethanol in Brazil. For instance, 5 US\$/GJ support help converting more than $60 \%$ of biorefineries into $2 \mathrm{G}$ ethanol option even if the electricity price is quite high in Brazil. On the other hand, when the investment cost of $2 \mathrm{G}$ option increases by two-fold (scenario Sc-5), 5 \$US/GJ biofuel support will only motivate the conversion of $23 \%$ of the biorefineries into the $2 \mathrm{G}$ option, resulting in $96 \mathrm{PJ}$ of ethanol exports to the EU, see Fig. 12(b).

When looking at the impact of biofuel support in Brazil (without ethanol export) at an elevated electricity price of $65 \$$ US/GJ (scenario Sc-10), 3-5 US\$/GJ support in terms of incentive/subsidies or green certificate would convert more than $90 \%$ of biorefineries into $2 \mathrm{G}$ ethanol option. However, $16.5 \mathrm{US} \$ \mathrm{GJ}$ biofuel support can only convert $51 \%$ of the biorefineries for the production of $2 \mathrm{G}$ ethanol when $50 \%$ more efficient power plant is considered (scenario Sc12).

At the moment, Brazil does not have carbon pricing scheme. Therefore, results on the impacts of carbon tax are indicative and it may not be directly applied in the present context. But it is evident that the policy support such as carbon tax is an efficient economic instrument to mitigation GHG emissions and it could significantly help to promote renewable energy using the carbon tax revenue $[70,71]$. The illustration helps provide a clear indication on the impacts of carbon tax for the production of bioelectricity and/or 2G ethanol in sugarcane biorefineries. The study finds that carbon tax does not have a significant impact when natural gas power is considered as marginal electricity in Brazil. But, if carbon intensive fossil based electricity (e.g. coal power) is considered as marginal

a. With condition of ethanol export to the EU (Sc-3)

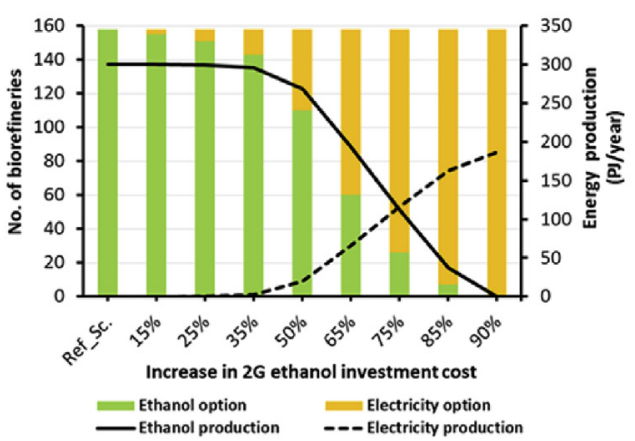

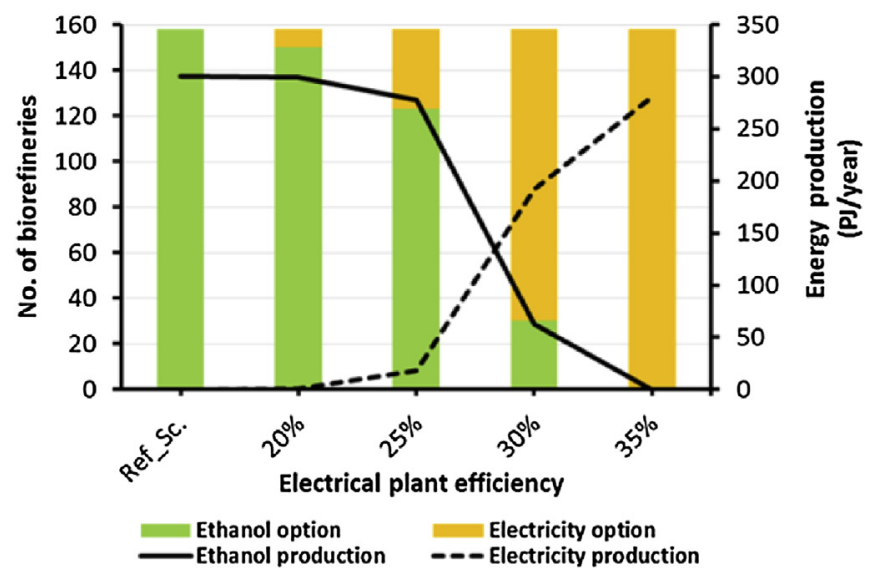

Fig. 11. Impact of power plant efficiency.

electricity (scenario Sc-6), carbon tax can play a key role in shifting $2 \mathrm{G}$ ethanol towards the electricity option as seen in Fig. 13. The study finds, in this case, that all plants would be converted into electricity option at a carbon tax of US\$ $150 \mathrm{tCO}_{2 \mathrm{eq}}$. Although coalfired power plants correspond to only $1.7 \%$ of the total installed capacity in Brazil [72], it is worth keeping in mind for the case of other countries.

It is important to mention that a carbon tax (US\$/tCO directly linked to the level of carbon dioxide equivalent $\left(\mathrm{CO}_{2 e q}\right)$ emissions. As part of energy sector reform and climate change mitigation actions, a few developed and developing countries have already introduced the carbon taxes [73]. For example, Sweden has introduced a carbon tax in 1991 and the value is US\$ 168 per $\mathrm{tCO}_{2 \mathrm{eq}}$ in 2014 [73]. Therefore, the inclusion of the carbon tax as a new regime for carbon compensation could play a vital role for substituting carbon-intensive fossil based electricity and promoting international biofuel trade in the EU.

Similarly, at a reduced gasoline price in the EU and thus without $2 \mathrm{G}$ ethanol export (scenario Sc-14), carbon tax will have an impact on the selection of technological options. For example, $60 \%$ of plants shift towards the electricity option when US\$250 $\mathrm{tCO}_{2 \mathrm{eq}}$ carbon tax is applied. It should be noted that marginal electricity for this scenario is natural gas power.

\section{Conclusions}

In Brazil, sugar and ethanol mills can be upgraded for low gasoline price: $<50 \$ / \mathrm{GJ})$ in the EU (Sc-11)

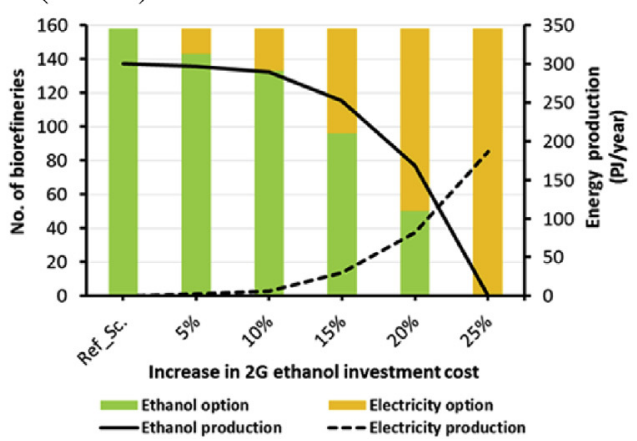

Fig. 10. Impacts of $2 \mathrm{G}$ ethanol investment costs (Sc-3 and Sc-11). 


\section{a. At high electricity price (i.e. $80 \$ / \mathrm{GJ}$ )} (Sc-2)

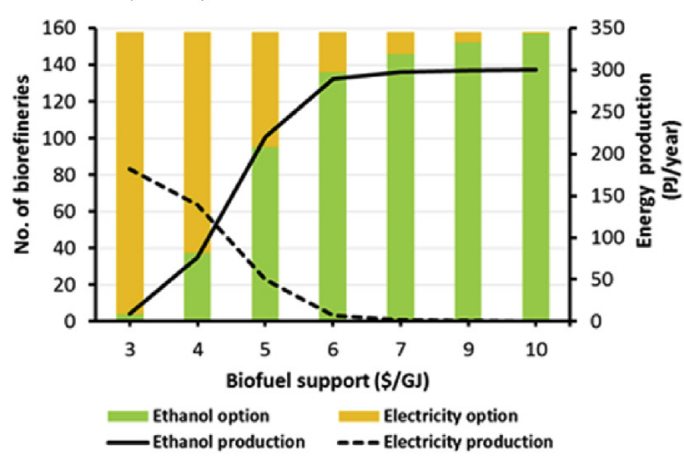

\section{b. At doubled $2 \mathrm{G}$ ethanol investment costs (Sc-5)}

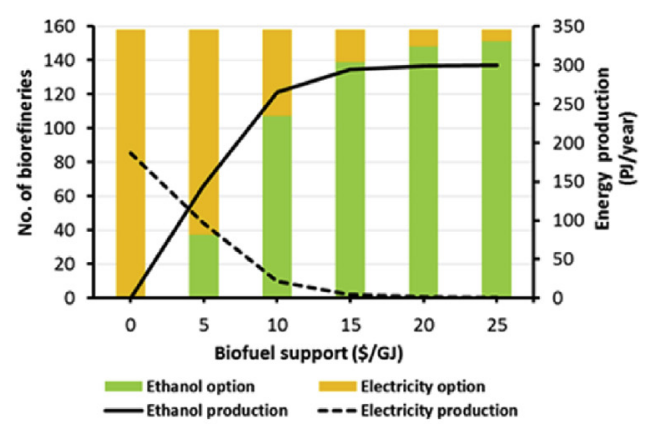

Fig. 12. Biofuel support when electricity price and investment costs are high.

bioelectricity and/or second generation $(2 \mathrm{G})$ bioethanol using residual sugarcane biomass (bagasse and trash). This study has investigated two technological pathways for improving the energy production capacity of existing sugarcane mills. Efficient cogeneration for bioelectricity and biochemical conversion technology for $2 \mathrm{G}$ ethanol are considered. All sugarcane mills located in the state of Sao Paulo in Brazil are included in the simulation.

The study performs a techno-economic analysis of the improved sugarcane biorefineries considering a spatially explicit optimization model for minimizing the system costs in the entire fuel chain. Carbon costs are internalized in the model. Bioelectricity is provided to the grid and second generation $(2 \mathrm{G})$ ethanol production allows exports to the EU. The model determines which technological option is optimal, and at what point exports are justified. As the size and location of biorefineries is different, the model selects a combination of technological options with distinct spatial location. This study would definitely complement the existing research studies on the optimization of biorefineries, taking into account the entire production chains of biofuel/bioelectricity production in the region (the state of Sao Paulo), domestic biofuel demand in Brazil and trade to the EU, associated market prices, and policy instruments.

At the reference scenario, with a relatively high cost of fossil based transport fuel in the EU and natural gas derived power as marginal electricity in Brazil, the $2 \mathrm{G}$ ethanol option is more favorable. Produced $2 \mathrm{G}$ ethanol would then be exported to the $\mathrm{EU}$, contributing to a share of $2.5 \%$ of the total transport fuel in the EU in

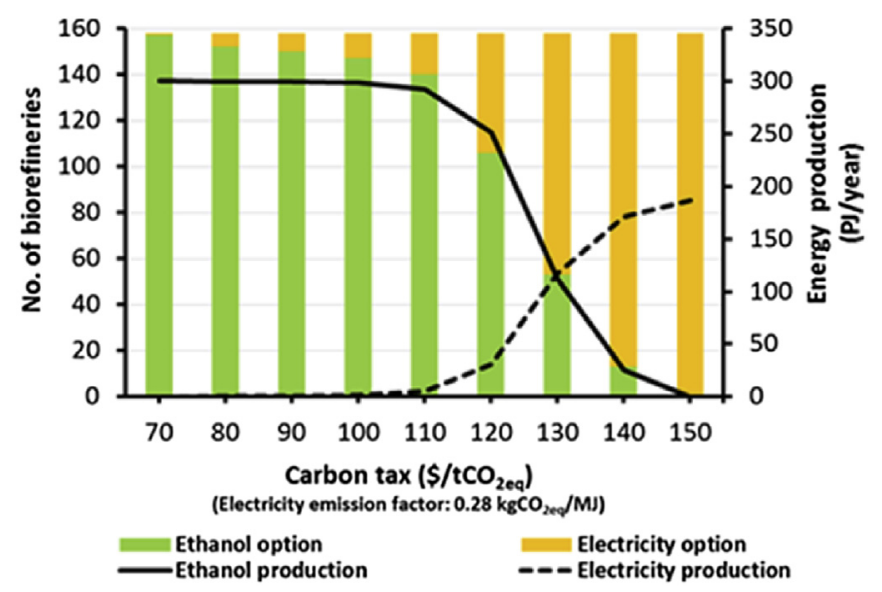

Fig. 13. Effects of carbon tax on carbon-intensive fossil based electricity (Sc-6).
2010.

Market and technological factors such as energy prices, plant efficiency and costs, type of substituted electricity, and policy instruments such as carbon tax and biofuel support are found to be the factors that most influence the outcome. When the price of electricity exceeds 75 US\$/GJ, all sugarcane mills would shift towards the bioelectricity option. The study finds that a gasoline price below $50 \mathrm{US} \$ / \mathrm{GJ}$ in the EU is not attractive to motivate exports of second generation (2G) ethanol from Brazil.

Conversion efficiency may also have a significant impact on the choice of technology. For example, if power plant efficiency is increased by $35 \%$ (i.e. $202.5 \mathrm{kWh} / \mathrm{t}$ cane), all plants are optimally selected to produce electricity. Biofuel support applied in the EU or in Brazil can promote the $2 \mathrm{G}$ ethanol option, even at a higher electricity price in Brazil or in the case of increased investment costs. When the investment cost of $2 \mathrm{G}$ ethanol option increases by two-fold, 5 \$US/GJ biofuel support is enough to convert 23\% of biorefineries into the $2 \mathrm{G}$ option, leading to exports of $96 \mathrm{PJ}$ of ethanol to the EU. The study finds that the generation of bioelectricity would be optimal when a combination of carbonintensive electricity and a high emission tax is applied in Brazil.

This study is mainly focused on the technological upgrading of existing sugarcane mills, but it would also be important to look into the new sugarcane mills as ethanol production expands. The model can be further developed for identifying the optimum size and location of the future sugarcane biorefineries for minimization of the total system costs and carbon costs in Brazil. It can also be applied to other sugarcane producing countries since there is a great potential to utilize surplus sugarcane biomass around the world. Different configurations such as stand-alone and integrated/ clustered or flexible, and conversion technologies, viz. thermochemical routes can also be simulated for finding suitable technological options, also considering both energy (power generation or biofuel production) and non-energy bioproducts.

Production of sugarcane is seasonal. There is also scope for utilizing other agricultural residues, e.g., rice husk and wheat straw, in synergy with sugarcane biorefineries for optimal production of energy services. Present studies on the performances of integrated and flexible biorefineries for the production of multiple energy and non-energy products/services should be incorporated in selecting important parameters (e.g. costs and conversion efficiencies) and their values which are the main inputs for this spatially explicit techno-economic model.

The model developed in this study could be useful in utilizing other abandoned or unutilized agricultural harvest residues and coproducts/residues left over from industrial processes for energy 
production since residual feedstock does not compete with food production and land use. The paper has presented the conditions and amount of $2 \mathrm{G}$ ethanol to be imported in the EU from Brazil. International trade of biofuels offers win-win opportunities to Brazil and the EU when it comes to meeting the national renewable targets, enhancing competitiveness of the biofuel industries, and promoting sustainable development.

\section{Acknowledgments}

This study is developed as part of the International Institute for Applied Systems Analysis (IIASA)'s Young Scientists Summer Program (YSSP) - three months' stay of Dilip Khatiwada - funded by the Swedish Research Council Formas. In addition, the authors acknowledge the REDD-PAC project supported by the International Climate Initiative of the Federal Ministry for the Environment, Nature Conservation and Nuclear Safety (BMU), Germany as well as IIASA Tropical Futures Initiative (TFI). The authors greatly thank two independent reviewers who provided valuable comments on this manuscript.

\section{References}

[1] Ministry of Mines and Energy (MME, Ministério de Minas e Energia), Brazilian Energy Balance - Year 2013, Federal Government of Brazil, 2014.

[2] W. Alonso Pippo, C.A. Luengo, L. Alonsoamador Morales Alberteris, P. Garzone, G. Cornacchia, Energy recovery from sugarcane-trash in the light of 2nd generation biofuels. Part 1: current situation and environmental aspects, Waste Biomass Valoriz. 2 (2010) 1-16, http://dx.doi.org/10.1007/s12649-0109048-0.

[3] M.R.L.V. Leal, A.S. Walter, J.E.A. Seabra, Sugarcane as an energy source, Biomass Convers. Bioref. 3 (2012) 17-26, http://dx.doi.org/10.1007/s13399 012-0055-1.

[4] UNICA, Brazilian Sugarcane Industry Association (Portuguese: União da Indústria de Cana-de-Açúcar), www.unica.com.br, Retrieved on August 2013.

[5] S.J. Hassuani, M.R.L.V. Leal, I.C. Macedo, Biomass Power Generation: Sugarcane Bagasse and Trash. Série Caminhos para Sustentabilidade, PNUD-CTC, Piracicaba, 2005

[6] J.E.A. Seabra, I.C. Macedo, Comparative analysis for power generation and ethanol production from sugarcane residual biomass in Brazil, Energy Policy 39 (2011) 421-428, http://dx.doi.org/10.1016/j.enpol.2010.10.019.

[7] A. Walter, A.V. Ensinas, Combined production of second-generation biofuels and electricity from sugarcane residues, Energy 35 (2010) 874-879, http:/ dx.doi.org/10.1016/j.energy.2009.07.032.

[8] W. Alonso Pippo, C.A. Luengo, L. Alonsoamador Morales Alberteris, P. Garzone, G. Cornacchia, Energy recovery from sugarcane-trash in the light of 2nd generation biofuel. Part 2: socio-economic aspects and techno-economic analysis, Waste Biomass Valoriz. 2 (2011) 257-266, http://dx.doi.org/ 10.1007/s12649-011-9069-3.

[9] M.O.S. Dias, M.P. Cunha, C.D.F. Jesus, G.J.M. Rocha, J.G.C. Pradella, C.E.V. Rossell, et al., Second generation ethanol in Brazil: can it compete with electricity production? Bioresour. Technol. 102 (2011) 8964-8971, http://dx.doi.org/ 10.1016/j.biortech.2011.06.098.

[10] S. Macrelli, J. Mogensen, G. Zacchi, Techno-economic evaluation of 2nd generation bioethanol production from sugar cane bagasse and leaves integrated with the sugar-based ethanol process, Biotechnol. Biofuels 5 (2012) 22, http:// dx.doi.org/10.1186/1754-6834-5-22.

[11] M.O.S. Dias, T.L. Junqueira, C.D.F. Jesus, C.E.V. Rossell, R. Maciel Filho, A. Bonomi, Improving second generation ethanol production through optimization of first generation production process from sugarcane, Energy 43 (2012) 246-252, http://dx.doi.org/10.1016/j.energy.2012.04.034.

[12] W. Antonio Bizzo, P.C. Lenço, D.J. Carvalho, J.P.S. Veiga, The generation of residual biomass during the production of bio-ethanol from sugarcane, its characterization and its use in energy production, Renew. Sustain Energy Rev. 29 (2014) 589-603, http://dx.doi.org/10.1016/j.rser.2013.08.056.

[13] J. Lee, B. Parameswaran, J. Lee, S. Park, Recent developments of key technologies on cellulosic ethanol production 67 (2008) 865-873.

[14] W. Alonso-pippo, C.A. Luengo, F.F. Fonseca, P. Garzone, G. Cornacchia Cogeneration and Bio-Oil Production Starting from Sugarcane Biomass Residues : Barriers, Challenges and Opportunities, 2009, pp. 34-39.

[15] International Energy Agency (IEA), Sustainable Production of Secondgeneration Biofuels: Potential and Perspectives in Major Economies and Developing Countries, 2010.

[16] P.S. Nigam, A. Singh, Production of liquid biofuels from renewable resources Prog. Energy Combust. Sci. 37 (2011) 52-68, http://dx.doi.org/10.1016/ j.pecs.2010.01.003.

[17] N.H. Leibbrandt, J.H. Knoetze, J.F. Görgens, Comparing biological and thermochemical processing of sugarcane bagasse: an energy balance perspective
Biomass Bioenergy 35 (2011) 2117-2126, http://dx.doi.org/10.1016/ j.biombioe.2011.02.017.

[18] S. Fernando, S. Adhikari, C. Chandrapal, N. Murali, Biorefineries: Current Status, Challenges, and Future Direction, 2006, pp. 1727-1737.

[19] H.R. Ghatak, Biorefineries from the perspective of sustainability: feedstocks, products, and processes, Renew. Sustain Energy Rev. 15 (2011) 4042-4052, http://dx.doi.org/10.1016/j.rser.2011.07.034.

[20] UNCTAD, The State of the Biofuels Market: Regulatory, Trade and Development Perspectives, The United Nations Conference on Trade and Development (UNCTAD), 2014.

[21] D. Khatiwada, J. Seabra, S. Silveira, A. Walter, Power generation from sugarcane biomass - a complementary option to hydroelectricity in Nepal and Brazil, Energy 48 (2012) 241-254, http://dx.doi.org/10.1016/ j.energy.2012.03.015.

[22] G.A. Dantas, L.F.L. Legey, A. Mazzone, Energy from sugarcane bagasse in Brazil: an assessment of the productivity and cost of different technological routes, Renew. Sustain Energy Rev. 21 (2013) 356-364, http://dx.doi.org/10.1016/ j.rser.2012.11.080.

[23] D.P. Ho, H.H. Ngo, W. Guo, A mini review on renewable sources for biofuel, Bioresour. Technol. 169 (2014) 742-749, http://dx.doi.org/10.1016/ j.biortech.2014.07.022.

[24] R. Zah, T.F. Ruddy, International trade in biofuels: an introduction to the special issue, J. Clean. Prod. 17 (2009) S1-S3, http://dx.doi.org/10.1016/ j.jclepro.2009.05.005.

[25] A.K. Chandel, S.S. da Silva, W. Carvalho, O.V. Singh, Sugarcane bagasse and leaves: foreseeable biomass of biofuel and bio-products, J. Chem. Technol. Biotechnol. 87 (2012) 11-20, http://dx.doi.org/10.1002/jctb.2742.

[26] J.E.A. Seabra, L. Tao, H.L. Chum, I.C. Macedo, A techno-economic evaluation of the effects of centralized cellulosic ethanol and co-products refinery options with sugarcane mill clustering, Biomass Bioenergy 34 (2010) 1065-1078, http://dx.doi.org/10.1016/j.biombioe.2010.01.042.

[27] T. Treasure, R. Gonzalez, R. Venditti, Y. Pu, H. Jameel, S. Kelley, et al., Coproduction of electricity and ethanol, process economics of value prior combustion, Energy Convers. Manag. 62 (2012) 141-153, http://dx.doi.org/ 10.1016/j.enconman.2012.04.002.

[28] M.O.S. Dias, T.L. Junqueira, O. Cavalett, M.P. Cunha, C.D.F. Jesus, C.E.V. Rossell, et al., Integrated versus stand-alone second generation ethanol production from sugarcane bagasse and trash, Bioresour. Technol. 103 (2012) 152-161, http://dx.doi.org/10.1016/j.biortech.2011.09.120.

[29] A. Corrêa do Lago, A. Bonomi, O. Cavalett, M. Pereira da Cunha, M.A. Pinheiro Lima, Sugarcane as a carbon source: the Brazilian case, Biomass Bioenergy 46 (2012) 5-12, http://dx.doi.org/10.1016/j.biombioe.2012.09.007.

[30] M.O.S. Dias, T.L. Junqueira, O. Cavalett, L.G. Pavanello, M.P. Cunha, C.D.F. Jesus, et al., Biorefineries for the production of first and second generation ethanol and electricity from sugarcane, Appl. Energy 109 (2013) 72-78, http:// dx.doi.org/10.1016/j.apenergy.2013.03.081.

[31] F.F. Furlan, R.T. Filho, F.H.P.B. Pinto, C.B.B. Costa, A.J.G. Cruz, R.L.C. Giordano, et al., Bioelectricity versus Bioethanol from Sugarcane Bagasse : Is It Worth Being Flexible?, 2013, pp. 1-12.

[32] J.D. Stephen, W.E. Mabee, J.N. Saddler, Will second-generation ethanol be able to compete with first-generation ethanol? Opportunities for cost reduction, Biofuels Bioprod. Biorefining 6 (2012) 159-176.

[33] P.W. Tittmann, N.C. Parker, Q.J. Hart, B.M. Jenkins, A spatially explicit technoeconomic model of bioenergy and biofuels production in California, J. Transp. Geogr. 18 (2010) 715-728, http://dx.doi.org/10.1016/j.jtrangeo.2010.06.005.

[34] P. Lamers, C. Hamelinck, M. Junginger, A. Faaij, International bioenergy trade-a review of past developments in the liquid biofuel market, Renew. Sustain Energy Rev. 15 (2011) 2655-2676, http://dx.doi.org/10.1016/ j.rser.2011.01.022

[35] F. Mafakheri, F. Nasiri, Modeling of biomass-to-energy supply chain operations: applications, challenges and research directions, Energy Policy 67 (2014) 116-126, http://dx.doi.org/10.1016/j.enpol.2013.11.071.

[36] S. Leduc, F. Starfelt, E. Dotzauer, G. Kindermann, I. McCallum, M. Obersteiner, et al., Optimal location of lignocellulosic ethanol refineries with polygeneration in Sweden, Energy 35 (2010) 2709-2716, http://dx.doi.org/10.1016/ j.energy.2009.07.018.

[37] J. Schmidt, S. Leduc, E. Dotzauer, E. Schmid, Cost-effective policy instruments for greenhouse gas emission reduction and fossil fuel substitution through bioenergy production in Austria, Energy Policy 39 (2011) 3261-3280, http:// dx.doi.org/10.1016/j.enpol.2011.03.018.

[38] K. Natarajan, S. Leduc, P. Pelkonen, E. Tomppo, E. Dotzauer, Optimal locations for methanol and CHP production in Eastern Finland, Bioenergy Res. 5 (2011) 412-423, http://dx.doi.org/10.1007/s12155-011-9152-4.

[39] E. Wetterlund, S. Leduc, E. Dotzauer, G. Kindermann, Optimal use of forest residues in Europe under different policies-second generation biofuels versus combined heat and power, Biomass Convers. Bioref. 3 (2012) 3-16, http://dx.doi.org/10.1007/s13399-012-0054-2.

[40] M. Hiloidhari, D. Das, D.C. Baruah, Bioenergy potential from crop residue biomass in India, Renew. Sustain Energy Rev. 32 (2014) 504-512, http:// dx.doi.org/10.1016/j.rser.2014.01.025.

[41] A. Gupta, J.P. Verma, Sustainable bio-ethanol production from agro-residues: a review, Renew. Sustain Energy Rev. 41 (2015) 550-567, http://dx.doi.org/ 10.1016/j.rser.2014.08.032.

[42] J. Smithers, Review of sugarcane trash recovery systems for energy cogeneration in South Africa, Renew. Sustain Energy Rev. 32 (2014) 915-925, http:// 
dx.doi.org/10.1016/j.rser.2014.01.042.

[43] I.E.A. Bioenergy, From 1st-to 2nd-generation Biofuel Technologies: an Overview of Current Industry and RD\&D Activities, The International Energy Agency (IEA), 2008.

[44] L.F. Pellegrini, S. de Oliveira Junior, Combined production of sugar, ethanol and electricity: thermoeconomic and environmental analysis and optimization, Energy 36 (2011) 3704-3715, http://dx.doi.org/10.1016/ j.energy.2010.08.011.

[45] D. Yue, F. You, S.W. Snyder, Biomass-to-bioenergy and biofuel supply chain optimization: overview, key issues and challenges, Comput Chem. Eng. 66 (2014) 36-56, http://dx.doi.org/10.1016/j.compchemeng.2013.11.016.

[46] B.A. McCarl, A. Meeraus, P.V.D. Eijk, M. Bussieck, S. Dirkse, P. Steacy, F. Nelissen, Mccarl Expanded Gams. User Guide Version 23.6, GAMS Development Corporation, 2011.

[47] S. Leduc, Doctoral Thesis, Development of an Optimization Model for the Location of Biofuel Production Plants, vol. 72, Luleå University of Technology, Luleå, 2009.

[48] E. Wetterlund, Optimal Localisation of Biofuel Production on a European Scale, International Institute for Applied System Analysis, 2010. Laxenburg, Austria.

[49] S. Leduc, E. Wetterlund, E. Dotzauer, G. Kindermann, CHP or biofuel production in Europe? Energy Procedia 20 (2012) 40-49, http://dx.doi.org/10.1016/ j.egypro.2012.03.006.

[50] Sugar Cane Technology Center (CTC: Portuguese acronym for Centro de Tecnologia Canavieira), Personal Communication with Mr. Luiz Antonio Dias Paes (27 June 2012), Manager at CTC, Piracicaba, Brazil, 2012.

[51] A. Walter, M.V. Galdos, F.V. Scarpare, M.R.L.V. Leal, J.E.A. Seabra, M.P. da Cunha, et al., Brazilian sugarcane ethanol: developments so far and challenges for the future, Wiley Interdiscip. Rev. Energy Environ. 3 (2014) 70-92, http:// dx.doi.org/10.1002/wene.87.

[52] V. Dornburg, P.C. Faaij, Efficiency and economy of wood-fired biomass energy systems in relation to scale regarding heat and power generation using combustion and gasification technologies 21 (2001) 91-108.

[53] D.C.L. Remer, Design cost factors for scaling-up engineering equipment, Chem. Eng. Prog. 86 (1990) 77-81.

[54] J.D. Van den Wall Bake, M. Junginger, a. Faaij, T. Poot, a Walter, Explaining the experience curve: cost reductions of Brazilian ethanol from sugarcane, Biomass Bioenergy 33 (2009) 644-658, http://dx.doi.org/10.1016/ j.biombioe.2008.10.006.

[55] A. Bonomi, The Brazilian sugarcane industry: a Favorable Environment to Introduce lignocellulosic Ethanol Production Technologies, in: Advanced Biofuels in a Biorefinery Approach - Copenhagen, Denmark - February, 2012, 2012.

[56] C.L. Crago, M. Khanna, J. Barton, E. Giuliani, W. Amaral, Competitiveness of Brazilian sugarcane ethanol compared to US corn ethanol, Energy Policy 38 (2010) 7404-7415, http://dx.doi.org/10.1016/j.enpol.2010.08.016.

[57] Intergovernmental Panel on Climate Change (IPCC), Four Assessment Report (AR4) - Climate Change, 2007.

[58] A. Broch, S.K. Hoekman, S. Unnasch, A review of variability in indirect land use change assessment and modeling in biofuel policy, Environ. Sci. Policy 29 (2013) 147-157, http://dx.doi.org/10.1016/j.envsci.2013.02.002.
[59] J.E.A. Seabra, I.C. Macedo, H.L. Chum, C.E. Faroni, C.A. Sarto, Life cycle assessment of Brazilian sugarcane products: GHG emissions and energy use, Biofuels Bioprod. Biorefining 5 (2011) 519-532.

[60] GREET, The Greenhouse Gases, Regulated Emissions, and Energy Use in Transportation Model (GREET). Version 1, Argonne National Laboratory, 2011, 2011.

[61] I.C. Macedo, J.E.A. Seabra, J.E.A.R. Silva, Green house gases emissions in the production and use of ethanol from sugarcane in Brazil: the 2005/2006 averages and a prediction for 2020, Biomass Bioenergy 32 (2008) 582-595, http://dx.doi.org/10.1016/j.biombioe.2007.12.006.

[62] H.L. MacLean, S. Spatari, The contribution of enzymes and process chemicals to the life cycle of ethanol, Environ. Res. Lett. 4 (2009) 014001, http:/ dx.doi.org/10.1088/1748-9326/4/1/014001.

[63] European Commission (EC), Directive 2009/28/EC of the European Parliament and of the Council of 23 April 2009 on the Promotion of the Use of Energy from Renewable Sources and Amending and Subsequently Repealing Directives 2001/77/EC and 2003/30/EC, 2009.

[64] California Air Resource Board (CARB), Staff Report: Detailed CaliforniaModified GREET Pathway for Brazilian Sugar Cane Ethanol, Version 2.2, Stationary Source Division, Release Date: July 20, 2009.

[65] BP Statistical Review of World Energy, bp.com/statisticalreview, Retrieved on December 2013.

[66] ANEEL, The Brazilian Electricity Regulatory Agency, (Portuguese: Agência Nacional de Energia Elétrica (ANEEL), www.aneel.gov.br, Retrieved on August 2013.

[67] Ministry of Mines and Energy (MME), Ministry of Mines and Energy (MME Ministério de Minas e Energia), Secretaria de Planejamento e Desenvolvimento Energético, Plano Decenal De Expansão De Energia 2020, Federal Government of Brazil, 2010. www.mme.gov.br.

[68] European Commission (EC), European Energy and Transport, Trends to 2030 Update 2007, European Commission Directorate-General for Energy and Transport, 2008.

[69] European Environment Agency (EEA), Percentage (\%) share of renewable energy in fuel consumption of transport by EU-27 Member State, http://www. eea.europa.eu/data-and-maps/figures/share-of-biofuels-in-transport-fuels-6, Retrieved on November 2013.

[70] G.R. Timilsina, S. Csordás, S. Mevel, When does a carbon tax on fossil fuels stimulate biofuels? Ecol. Econ. 70 (2011) 2400-2415, http://dx.doi.org/ 10.1016/j.ecolecon.2011.07.022.

[71] Y.-H.H. Chen, G.R. Timilsina, F. Landis, Economic implications of reducing carbon emissions from energy use and industrial processes in Brazil J. Environ. Manag. 130 (2013) 436-446, http://dx.doi.org/10.1016/ j.jenvman.2013.08.049.

[72] L.P.P. Nogueira, A. Frossard Pereira de Lucena, R. Rathmann, P. Rua Rodriguez Rochedo, A. Szklo, R. Schaeffer, Will thermal power plants with CCS play a role in Brazil's future electric power generation? Int. J. Greenhouse Gas Control 24 (2014) 115-123, http://dx.doi.org/10.1016/j.ijggc.2014.03.002.

[73] World Bank, Putting a Price on Carbon with a Tax, http://www.worldbank. org/content/dam/Worldbank/document/SDN/background-note_carbon-tax. pdf, Retrieved on February 2015. 